\title{
Novel Adamantanyl-Based Thiadiazolyl Pyrazoles Targeting EGFR in Triple-Negative Breast Cancer
}

Anusha Sebastian, ${ }^{\dagger, \bowtie}$ Vijay Pandey, ${ }^{\ddagger, \S, \bowtie}$ Chakrabhavi Dhananjaya Mohan, ${ }^{\|, \perp, \bowtie}$ Yi Ting Chia, ${ }^{\ddagger, \S}$ Shobith Rangappa, ${ }^{\#}$ Jessin Mathai, ${ }^{\nabla}$ C. P. Baburajeev, ${ }^{\dagger}$ Shardul Paricharak, ${ }^{\circ}$ Lewis H. Mervin, ${ }^{\bigcirc}$ Krishna C. Bulusu, ${ }^{\bigcirc}$ Julian E. Fuchs, ${ }^{\bigcirc}$ Andreas Bender, ${ }^{\bigcirc}$ Shuhei Yamada, ${ }^{\text {II }}$ Basappa, ${ }^{*}, \dagger$ Peter E. Lobie,** and Kanchugarakoppal S. Rangappa*,\|

${ }^{\dagger}$ Laboratory of Chemical Biology, Department of Chemistry, Bangalore University, Central College campus, Palace Road, Bangalore560001, India

${ }^{\ddagger}$ Cancer Science Institute of Singapore and ${ }^{\S}$ Department of Pharmacology, National University of Singapore, 14 Medical Drive \#11-02, MD6, Singapore 117599, Singapore

${ }^{\|}$Department of Studies in Chemistry and ${ }^{\perp}$ Department of Studies in Molecular Biology, University of Mysore, Manasagangotri, Mysore 570006, India

\#Frontier Research Center for Post-Genome Science and Technology, Hokkaido University, Sapporo 060-0808, Japan

${ }^{\nabla}$ Centre for Advanced Biomedical Research and Innovation, Gulf Medical University, Ajman 4184, United Arab Emirates

${ }^{\circ}$ Department of Chemistry, Centre for Molecular Informatics, University of Cambridge, Lensfield Road, Cambridge CB2 1EW, U.K.

Division of Medicinal Chemistry, Leiden Academic Centre for Drug Research, Leiden University, P.O. Box 9502, Leiden 2300 RA, The Netherlands

IIDepartment of Pathobiochemistry, Faculty of Pharmacy, Meijo University, Nagoyo 468-8503, Japan

Supporting Information

ABSTRACT: The epidermal growth factor receptor (EGFR) is a validated therapeutic target for triple-negative breast cancer (TNBC). In the present study, we synthesize novel adamantanyl-based thiadiazolyl pyrazoles by introducing the adamantane ring to thiazolopyrazoline. On the basis of loss of cell viability in TNBC cells, 4-(adamantan-1-yl)-2-(3-(2,4-dichlorophenyl)-5-phenyl-4,5-dihydro- $1 H$-pyrazol-1-yl)thiazole (APP) was identified as a lead compound. Using a Parzen-Rosenblatt Window classifier, APP was predicted to target the EGFR protein, and the same was confirmed by surface plasmon resonance. Further analysis revealed that APP suppressed the phosphorylation of EGFR at Y992, Y1045, Y1068, Y1086, Y1148, and Y1173 in TNBC cells. APP also inhibited the phosphorylation of ERK at Y204 and of STAT3 at Y705, implying that APP downregulates the

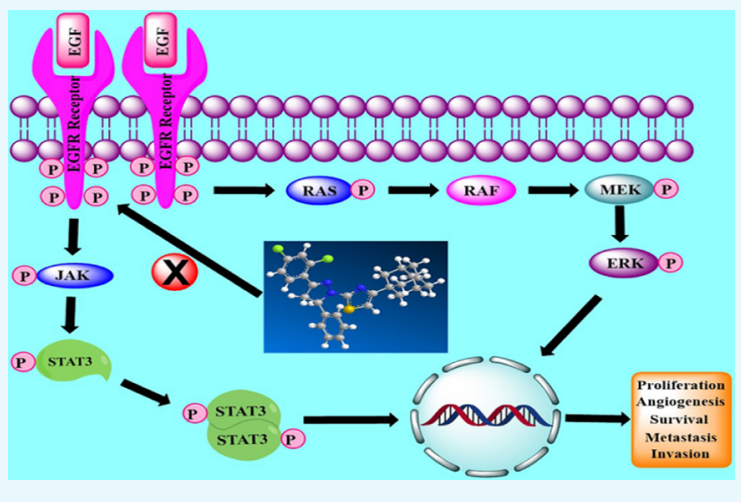
activity of EGFR downstream effectors. Small interfering RNA mediated depletion of EGFR expression prevented the effect of APP in BT549 and MDA-MB-231 cells, indicating that APP specifically targets the EGFR. Furthermore, APP modulated the expression of the proteins involved in cell proliferation and survival. In addition, APP altered the expression of epithelial-mesenchymal transition related proteins and suppressed the invasion of TNBC cells. Hence, we report a novel and specific inhibitor of the EGFR signaling cascade.

\section{INTRODUCTION}

Triple-negative breast cancer (TNBC) is an aggressive subtype of breast cancer distinguished by the lack of human epidermal growth factor receptor 2 (HER2-negative, also known as HER2/ neu and ErbB2), estrogen receptor (ER-negative), and progesterone receptor (PR-negative); hence, this subtype is not responsive to effective targeted therapeutics used in breast cancer. ${ }^{1,2}$ Approximately $15 \%$ of diagnosed breast cancer is triple negative and is associated with a poor prognosis. ${ }^{3}$ Therefore, the identification and validation of potential therapeutic targets involved in the regulation of cell proliferation, survival, metastasis, and chemoresistance in TNBC have attracted significant attention in cancer drug discovery. ${ }^{4}$ The epidermal growth factor receptor (EGFR) is an earlier proposed target for cancer treatment, its expression is increased in TNBC, and is significantly associated with a negative prognosis in TNBC. ${ }^{5}$

Received: September 18, 2016

Accepted: December 15, 2016

Published: December 28, 2016 


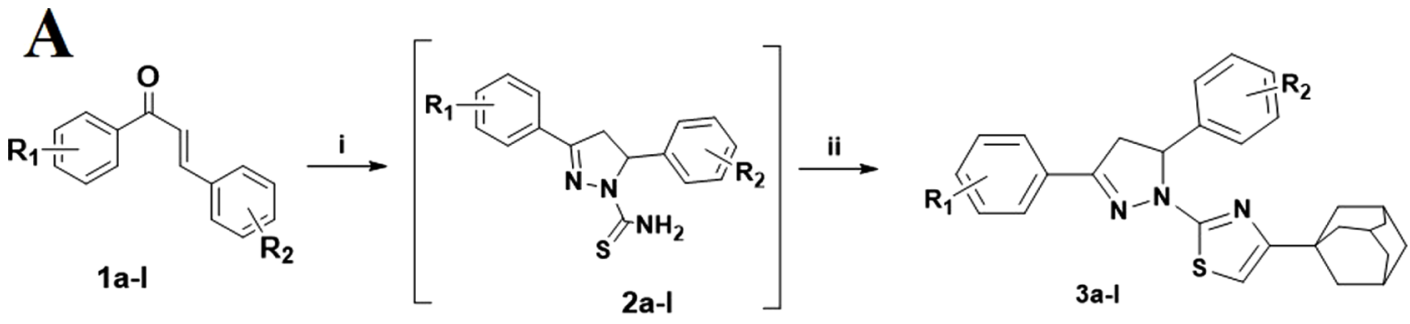

$\mathrm{i}=[\mathrm{BMIM}]\left[\mathrm{BF}_{4}\right]$, Thiosemicarbazide, piperidine $, 80^{\circ} \mathrm{C}, 4 \mathrm{~h}$

$\mathrm{ii}=2$-(adamantan-1-yl)acetylbromide, $80^{\circ} \mathrm{C}, 2 \mathrm{~h}$.

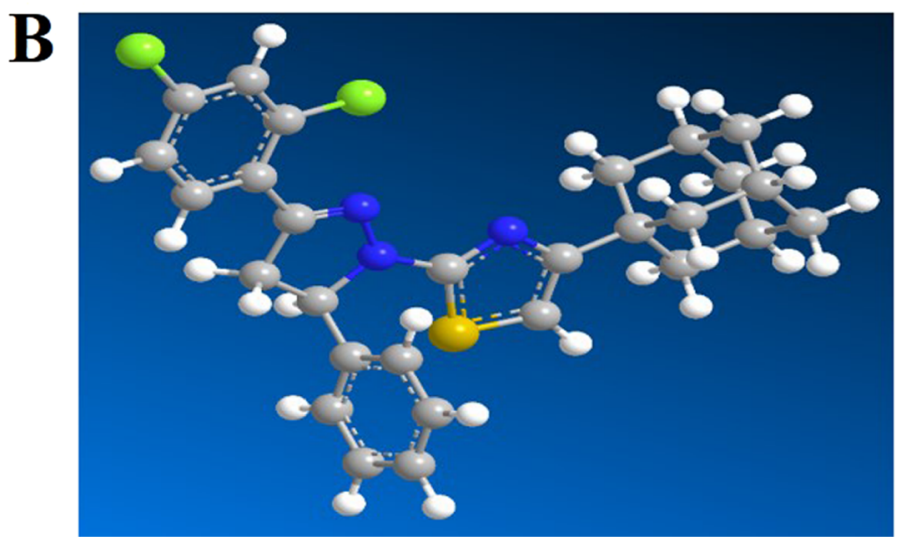

Figure 1. Generation of novel compound series for potential anticancer agents. (A) Schematic representation of the synthesis of title compounds. (B) Structure of APP.

Several targeted therapeutics have entered clinical trials, but unfortunately, none of them have yet been approved for TNBC. ${ }^{6}$ Therefore, treatment of TNBC remains an unmet need. Studies have revealed that targeting the EGFR improved the sensitivity of TNBC to cytotoxic agents by promoting apoptosis in TNBC cells, and several EGFR inhibitors have been approved for the treatment of other cancers. ${ }^{7}$

The binding of ligand to the extracellular domain of EGFR leads to the activation of EGFR tyrosine kinase activity, resulting in the phosphorylation of a series of tyrosine residues (Y992, Y1068, Y1086, Y1148, and Y1173) in the carboxy-terminal domain. ${ }^{8}$ The autophosphorylation of tyrosine residues provides docking sites for cytoplasmic proteins containing Src homology 2 (SH2) and phosphotyrosine-binding domains. ${ }^{9}$ The interaction of cytoplasmic proteins with the specific phosphotyrosine residues of the EGFR results in the initiation of the intracellular signaling cascade via several pathways. ${ }^{10}$ Lapatinib is a quinazoline-based small-molecule inhibitor of the EGFR, which has been approved for the treatment of metastatic TNBC. ${ }^{11}$ Gefitinib, erlotinib, cetuximab, and panitumumab are also the approved drugs targeting the EGFR for the treatment of various types of cancers. ${ }^{12}$ Therefore, EGFR inhibitors may provide substantial clinical benefit for patients with TNBC. Thus, the development of novel EGFR inhibitors may provide a promising therapeutic approach for TNBC.

Thiazole, pyrazole, and adamantane derivatives have been studied for their antitumor activity by several research groups and reported to possess significant in vitro and in vivo anticancer activity against a broad range of cancers. ${ }^{13-16}$ Dasatinib (BMS354825; Bristol-Myers Squibb) is a thiazole derivative that inhibits the growth of breast cancer cells by targeting the EGFR signaling pathway. ${ }^{17}$ Furthermore, it has been reported that pyrazole derivatives inhibit the EGFR kinase activity in breast cancer cells at nanomolar concentrations. ${ }^{18}$ In addition, conjugated thiazolyl-pyrazoline derivatives were demonstrated to possess potent EGFR kinase inhibitory activities. ${ }^{19}$ Lamoureux and colleagues have summarized the importance of the adamantane group in modulating the ADME profile of known drugs and identified adamantanes as an important pharmacophore for the design of new drugs. ${ }^{20}$ In the present article, we generated a new structure, 4-(adamantan-1-yl)-substituted-(4,5dihydro- $1 H$-pyrazol-1-yl)thiazole (APT), by introducing the adamantane ring to the thiazolopyrazoline scaffold and demonstrated the effect of the lead compound on EGFR signaling.

\section{RESULTS}

Chemistry. The synthetic route employed in the synthesis of the thiazolyl-pyrazoline derivatives is represented in Figure 1a. Initially, chalcones $\mathbf{1 a}-\mathbf{l}$ were prepared by condensation of equimolar amounts of substituted aldehydes and ketones under base-catalyzed conditions. The obtained chalcones, $\mathbf{1 a}-\mathbf{1}$, were refluxed with equimolar amount of thiosemicarbazide in 1-butyl3-methylimidazolium tetrafluoroborate $[\mathrm{BMIM}]\left[\mathrm{BF}_{4}\right]$ using catalytic amount of piperidine to generate dihydropyrazole intermediate 2a-1. Thereafter, 2-(adamantan-1-yl)acetylbromide was added to dihydropyrazole intermediate $\mathbf{2 a -}$ $\mathbf{l}$ in situ to generate the title compounds, 3a-l (Figure 1A). All of the new compounds exhibited spectral properties consistent with the assigned structures and were fully characterized by their spectroscopic data $\left({ }^{1} \mathrm{H}, \mathrm{IR}\right.$, mass, elemental, and ${ }^{13} \mathrm{C}$ NMR analyses). Spectra for the new compounds are provided as Supporting Information.

APTs Exhibit Growth Inhibitory Effect on TNBC Cells. We initially examined the growth inhibitory effects of APTs against the panel of eight breast cancer cell lines, including 
Table 1. IC $_{50}$ Values of Novel Compound Series (APTs) in a Range of Mammary Carcinoma (MC) Cell Lines ${ }^{a}$

\begin{tabular}{|c|c|c|c|c|c|c|c|c|}
\hline \multirow[b]{3}{*}{ entry } & \multicolumn{8}{|c|}{ cells } \\
\hline & MCF7 & T47D & BT474 & BT549 & MDA-MB-231 & MDA-MB-468 & HCC70 & BT20 \\
\hline & $\mathrm{IC}_{50} \pm \mathrm{SD}(\mu \mathrm{M})$ & $\mathrm{IC}_{50} \pm \mathrm{SD}(\mu \mathrm{M})$ & $\mathrm{IC}_{50} \pm \mathrm{SD}(\mu \mathrm{M})$ & $\mathrm{IC}_{50} \pm \mathrm{SD}(\mu \mathrm{M})$ & $\mathrm{IC}_{50} \pm \mathrm{SD}(\mu \mathrm{M})$ & $\mathrm{IC}_{50} \pm \mathrm{SD}(\mu \mathrm{M})$ & $\mathrm{IC}_{50} \pm \mathrm{SD}(\mu \mathrm{M})$ & $\mathrm{IC}_{50} \pm \mathrm{SD}(\mu \mathrm{M})$ \\
\hline $3 a$ & $22.6 \pm 7.94$ & $19.8 \pm 3.44$ & $18.1 \pm 2.95$ & $28.6 \pm 7.43$ & $12.9 \pm 4.28$ & $22.2 \pm 9.63$ & $19.1 \pm 9.2$ & $\mathrm{NV} \pm \mathrm{NV}$ \\
\hline $3 b$ & $\mathrm{NV} \pm \mathrm{NV}$ & $\mathrm{NV} \pm \mathrm{NV}$ & $\mathrm{NV} \pm \mathrm{NV}$ & $27.4 \pm 5.32$ & $23 \pm 3.75$ & $\mathrm{NV} \pm \mathrm{NV}$ & $\mathrm{NV} \pm \mathrm{NV}$ & $31.4 \pm 8.82$ \\
\hline $3 c$ & $16.5 \pm 3.62$ & $12.6 \pm 2.64$ & $28.4 \pm 7.49$ & $15.3 \pm 4.25$ & $22.5 \pm 7.48$ & $13.7 \pm 3.42$ & $7.55 \pm 2.32$ & $20.4 \pm 6.93$ \\
\hline $3 d$ & $\mathrm{NV} \pm \mathrm{NV}$ & $\mathrm{NV} \pm \mathrm{NV}$ & $\mathrm{NV} \pm \mathrm{NV}$ & $24.5 \pm 4.38$ & $44.4 \pm 12.6$ & $18.6 \pm 4.37$ & $38.9 \pm 9.63$ & $29.5 \pm 8.31$ \\
\hline $3 e$ & $12.9 \pm 2.49$ & $9.92 \pm 3.54$ & $14.7 \pm 3.21$ & $4.92 \pm 0.97$ & $5.34 \pm 0.72$ & $7.55 \pm 1.04$ & $5.96 \pm 1.17$ & $9.62 \pm 0.89$ \\
\hline $3 f$ & $17.5 \pm 3.89$ & $15.3 \pm 4.24$ & $21.8 \pm 4.67$ & $14 \pm 2.66$ & $9.72 \pm 2.01$ & $5.83 \pm 1.31$ & $8.02 \pm 3.99$ & $13.7 \pm 2.31$ \\
\hline $3 g$ & $\mathrm{NV} \pm \mathrm{NV}$ & $\mathrm{NV} \pm \mathrm{NV}$ & $\mathrm{NV} \pm \mathrm{NV}$ & $\mathrm{NV} \pm \mathrm{NV}$ & $\mathrm{NV} \pm \mathrm{NV}$ & $\mathrm{NV} \pm \mathrm{NV}$ & $\mathrm{NV} \pm \mathrm{NV}$ & $\mathrm{NV} \pm \mathrm{NV}$ \\
\hline $3 \mathrm{~h}$ & $29.1 \pm 6.97$ & $31.6 \pm 8.38$ & $41.3 \pm 10.3$ & $19.4 \pm 4.28$ & $\mathrm{NV} \pm \mathrm{NV}$ & $\mathrm{NV} \pm \mathrm{NV}$ & $35.8 \pm 11.3$ & $31.4 \pm 9.26$ \\
\hline $3 \mathbf{i}$ & $16.5 \pm 4.69$ & $22.5 \pm 4.09$ & $37.4 \pm 11.6$ & $32.5 \pm 10.4$ & $\mathrm{NV} \pm \mathrm{NV}$ & $12.5 \pm 4.91$ & $21.6 \pm 5.05$ & $14.3 \pm 3.93$ \\
\hline $3 \mathbf{j}$ & $38.5 \pm 10.5$ & $\mathrm{NV} \pm \mathrm{NV}$ & $57.3 \pm 11.4$ & $17.9 \pm 2.08$ & $27.6 \pm 8.31$ & $34.4 \pm 8.46$ & $N V \pm N V$ & $27.1 \pm 5.94$ \\
\hline $3 k$ & $\mathrm{NV} \pm \mathrm{NV}$ & $\mathrm{NV} \pm \mathrm{NV}$ & $24.5 \pm 11$ & $42.2 \pm 9.31$ & $34.9 \pm 12$ & $19 \pm 2.31$ & $22.6 \pm 8.15$ & $39.5 \pm 14.8$ \\
\hline 31 & $\mathrm{NV} \pm \mathrm{NV}$ & $N V \pm N V$ & $N V \pm N V$ & $\mathrm{NV} \pm \mathrm{NV}$ & $N V \pm N V$ & $\mathrm{NV} \pm \mathrm{NV}$ & $\mathrm{NV} \pm \mathrm{NV}$ & $\mathrm{NV} \pm \mathrm{NV}$ \\
\hline
\end{tabular}

${ }^{a} \mathrm{NV}$, no value; $\mathrm{IC}_{50}$ values were calculated using GraphPad Prism software (version 5.0). Cell viability was measured using AlamarBlue cell viability assay.

MCF7, T47D, BT474, BT549, MDA-MB-231, MDA-MB-468, HCC70, and BT20, using the AlamarBlue assay, and the $\mathrm{IC}_{50}$ values are given in Table 1 . Among the tested compounds, 4(adamantan-1-yl)-2-(3-(2,4-dichlorophenyl)-5-phenyl-4,5-dihydro-1H-pyrazol-1-yl)thiazole (APP; Figure 1B) was observed to be the most effective among the structural variants in decreasing the viability of the tested cell lines (Table S2). Notably, APP reported the highest growth inhibitory effect against BT549 (TNBC) with an $\mathrm{IC}_{50}$ of $4.9 \mu \mathrm{M}$ compared to that against other TNBCs (Table S2).

APP Exposure to BT549 Cells Decreases Cell Proliferation. Therefore, next we determined the effect of APP on cell proliferation of BT549 cells. APP exposure resulted in a reduction of BT549 total cell count in a dose-dependent manner (Figure 2A). Increased cell number results from the net effect of increased cell proliferation and/or a decrease in apoptotic cell death. $^{21,22}$ The fragmentation of internucleosomal DNA is one of the prominent characteristic features of cell apoptosis and the frequency if cells with DNA content can be detected using flow cytometric analysis. ${ }^{23,24}$ To evaluate the effect of APP on the cell cycle of BT549 cells, we analyzed the cell cycle distribution pattern of BT549 cells following treatment with APP using flow cytometry. BT549 cells were treated with APP at different doses up to $5 \mu \mathrm{M}$ for $24 \mathrm{~h}$. We observed the gradual accumulation of cells in the subG1 phase to 7.5, 17.2, and 50.3\% after treatment with $1.25,2.5$, and $5 \mu \mathrm{M} \mathrm{APP}$, respectively (Figure 2B). Moreover, BT549 cells treated with different concentrations of APP for $24 \mathrm{~h}$ were stained with Hoechst 33342 dyes and examined for condensed chromatin, which is a feature of apoptosis in cancer cells. Only BT549 cells treated with 2.5 and 5 $\mu \mathrm{M}$ of APP resulted in a significant increase in the percentage of condensed chromatin as compared to the control (Figure 2C), suggesting that APP possibly induces apoptosis in BT549. Thus, APP exposure to BT549 suppresses cell proliferation.

Computational Mode-of-Action Analysis for APTs. In an attempt to rationalize the observed inhibitory effect of the APTs on TNBC cells, we predicted potential human protein targets using ligand-based cheminformatic approaches. The first method used was the Parzen-Rosenblatt Window classifier trained on bioactivity data extracted from ChEMBL, as previously deployed by Koutsoukas et al., where the probability cutoff was set to be $0.05{ }^{25}$ Targets predicted for the APTs with a probability above the cutoff specified are depicted in Table S2.
The second method employed a Bernoulli Näive Bayes classifier trained on active bioactivity data obtained from $\mathrm{ChEMBL}^{26}$ and negative bioactivity data extracted from PubChem. ${ }^{27}$ Predictions from this tool ranked the EGFR highly, in the top $10 \%$ of predicted targets across the average of all of the APTs. These results indicate that the potential in silico mode of action of the APTs was to the EGFR.

In Silico Molecular Interactions of APP with EGFR. The in silico analysis revealed that all APTs target the EGFR, which was consistently predicted across algorithms with a higher rank of the probability factor of greater than 0.60 . Therefore, we decided to identify potential protein-ligand interactions using a molecular docking approach. We used the crystal structure of the EGFR tyrosine kinase domain in complex with a similar hydrophobic inhibitor (PDB: 3W33) as the basis for our studies. ${ }^{28}$ In silico docking predicted a common binding mode for the series of APTs that shows a major overlap with the binding present in the crystal structure (Figure $3 \mathrm{~A}$ ). Intramolecular hydrophobic interactions assist the conformation of APP to occupy the binding groove of the EGFR kinase domain. Thereby, prominent hydrophobic interactions with Leu-718 and Val-726 of the EGFR are predicted. Additionally, a hydrogen bond with Lys-745 is formed. The chlorine substituents of APP showing the highest biological activity optimize the shape fit of the compounds, thus providing a basic molecular explanation for the observed structure-activity relationships. In correlation with this, the hydrophobic naphthalene that is fused to the pyrazole, a reference compound, was predicted to dock into the kinase domain of EGFR, which showed that the naphthalene ring formed $\pi-\pi$ bonds with Lys-721, which may lead to enhanced antitumor activity. ${ }^{29}$

SPR Analysis of APP with EGFR. Next, we examined the potential interaction between APP and EGFR by SPR analysis using the BIACORE system as described previously. ${ }^{30}$ The amino terminal of the EGFR was immobilized on the surface of a CM5 sensor chip, and rest of the EGFR molecule including the kinase domain was allowed to interact with APP. Four different concentrations of APP $(10,20,30$, and $40 \mu \mathrm{M})$ were passed as analytes. The sensogram curves revealed the dose-dependent increase in the interaction of immobilized protein with APP (Figure 3B). The association and dissociation curves were used to calculate the kinetic parameters for the interaction of APP with EGFR, which revealed the association rate constant of $(6.59 \pm$ 


\section{A. Total cell count}
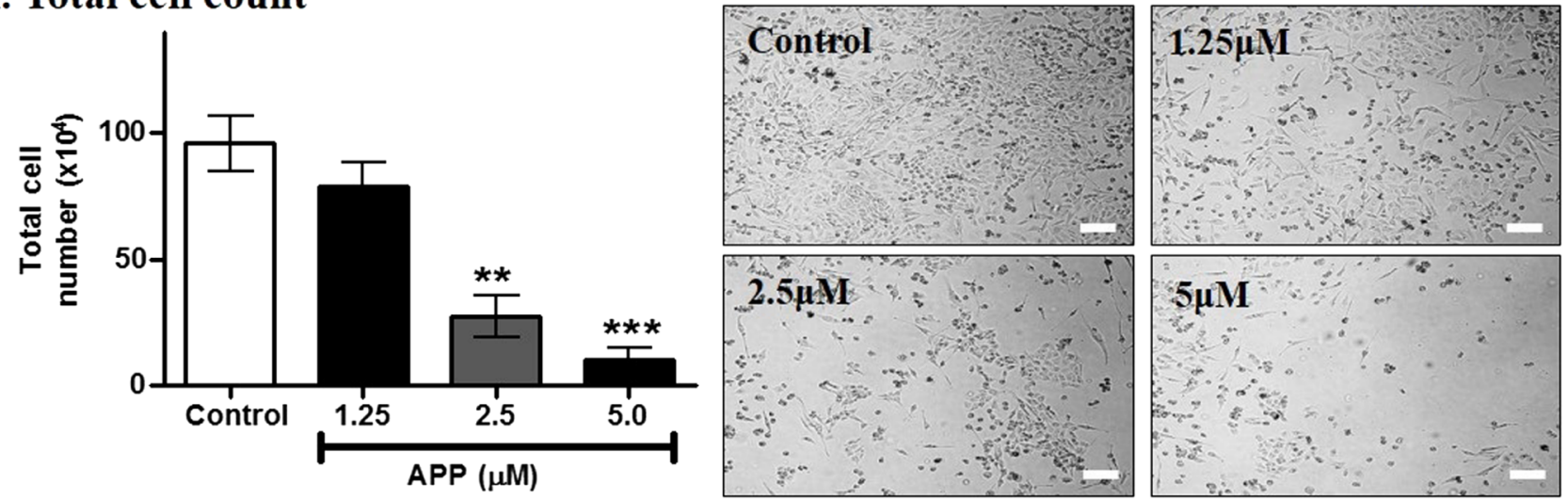

B. Cell cycle analysis

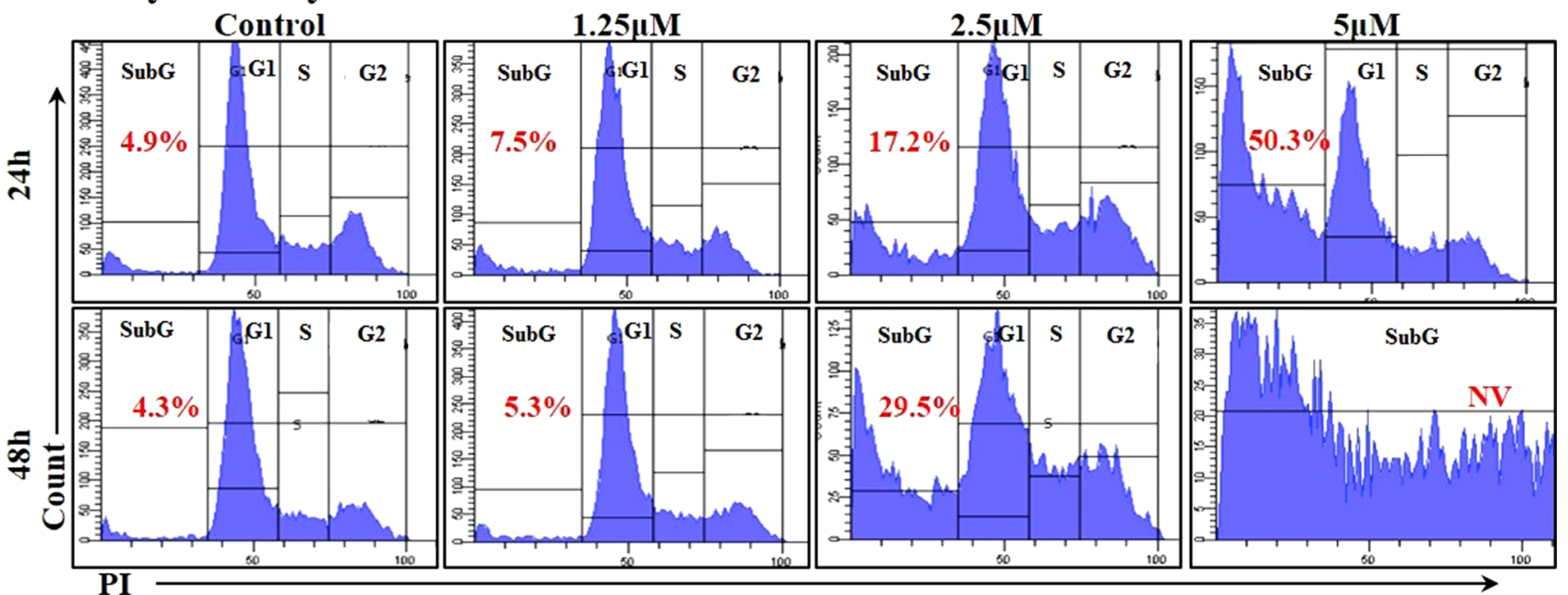

\section{Apoptosis}
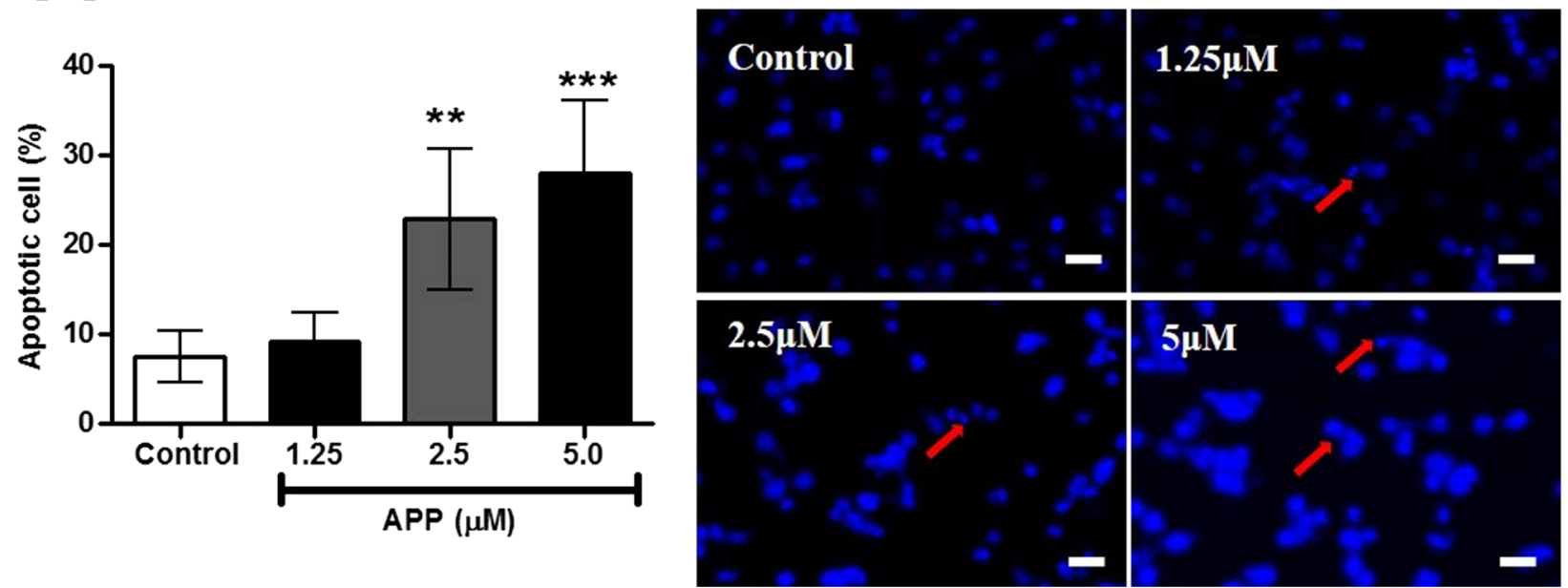

Figure 2. Exposure of APP to BT549 cells decreases cell proliferation and stimulate apoptotic cell death. (A) Total cell count of BT549 cells cultured in complete media for 6 days after exposure to different concentrations of APP and vehicle control (dimethyl sulfoxide (DMSO)). The morphology of BT549 cells after exposure to APP and vehicle control is represented on the right side. Images were captured under 100× magnification. (B) BT549 cells were treated with different concentrations of $\operatorname{APP}(0,1.25,2.5$, and $5.0 \mu \mathrm{M})$ for $24 \mathrm{~h}$, and cell cycle distribution was analyzed by staining with propidium iodide (PI) using flow cytometry. The analysis revealed that APP accumulates BT549 cells in the SubG1 phase, indicating that cells are committed to apoptosis. (C) BT549 cells were treated with different concentrations of APP $(0,1.25,2.5$, and $5.0 \mu \mathrm{M})$ for $24 \mathrm{~h}$, and apoptotic cell distribution was analyzed by Hoechst 33258 staining using confocal microscopy. Images of BT549 cells after exposure to APP and vehicle control are represented on the right side. Images were captured under 100× magnification. All assays were performed as described in Methods. Column points are mean of triplicate experiments; bars, \pm standard deviation (SD). $* p<0.05, * * p<0.01$, and $* * * p<0.001$. 
A
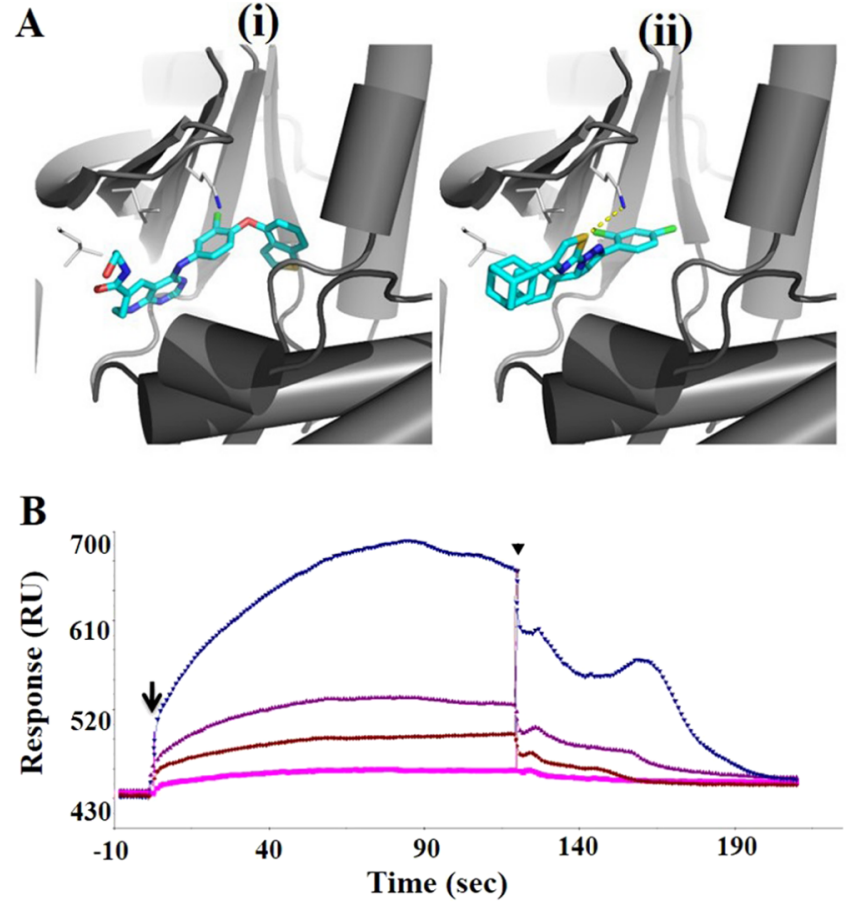

C. Western blot

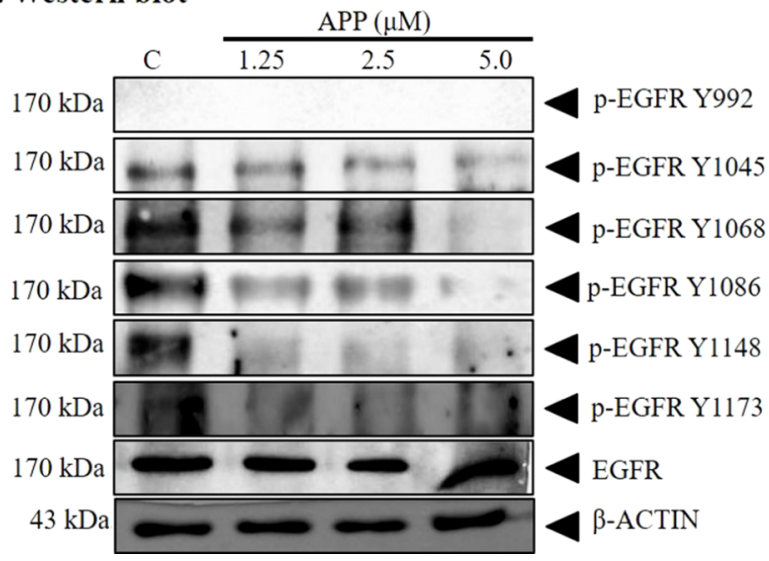

Figure 3. Cheminformatics and surface plasmon resonance (SPR) analysis predicts the interaction of APP with the EGFR protein. (A) Predicted molecular interactions between EGFR and APP: (i) Template crystal structure of EGFR (gray cartoon) in complex with a hydrophobic kinase inhibitor (cyan cartoon). (ii) The predicted binding mode of APP shows a major shape overlap with the co-crystallized ligand. Main interaction centers are highlighted as thin sticks and include Leu-718, Val-726, and Lys-745, which form hydrogen bonds to the ligand (yellow dots). (B) The sensorgrams obtained by SPR analysis of APP with the EGFR protein subunit. The EGFR protein subunit was immobilized onto the surface of a CM5 sensor chip. A solution of APP at variable concentrations was injected to generate the results of binding responses (RU) recorded as a function of time (s). The results were analyzed using BIA evaluation 3.1. (C) Western blot analysis was performed to evaluate the effect of APP on EGFR phosphorylation (at Y992, Y1068, Y1086, Y1148, and Y1173) in BT549 cells. Soluble whole cell extracts were run on sodium dodecyl sulfate-polyacrylamide gel electrophoresis (SDSPAGE) and immunoblotted as described in Methods. $\beta$-Actin was used as input control for cell lysate. The sizes of the detected protein bands in kilodaltons are shown on the left side.

$0.10) \times 10^{4} \mathrm{M}^{-1} \mathrm{~s}^{-1}$ and dissociation rate constant of (77.76 \pm $4.09) \times 10^{-2} \mathrm{~s}^{-1}$ of binding affinity, which yielded dissociation equilibrium constants $\left(K_{\mathrm{d}}\right)$ of $11.8 \pm 2.40 \mu \mathrm{M}$. These data indicate that APP exhibited molecular interaction with the EGFR protein.

APP Inhibits Tyrosine Phosphorylation of EGFR in BT549 Cells. Phosphorylation of several tyrosine residues present in the C-terminal domain of the EGFR contributes to activation of downstream signaling pathways via $\mathrm{SH} 2$ domain interaction. ${ }^{31,32}$ Therefore, inhibition of phosphorylation of specific tyrosine residues abrogates multiple growth-promoting pathways. ${ }^{33}$ To determine if APP indeed targets the EGFR as predicted by the in silico computational analysis, we analyzed the effect of APP on the phosphorylation of key tyrosine residues of the EGFR using western blot analysis. As shown in Figure 3C, phosphorylation of tyrosine at 1045, 1068, 1086, 1148, and 1173 was observed to be decreased in a dose-dependent manner, with a maximum inhibition at $5 \mu \mathrm{M}$ and without change in the expression of the EGFR.

APP Induces Apoptosis in BT549 Cells in ThreeDimensional (3D) Culture and Decreases the Expression of EGFR Downstream Effectors. Cancer cells often offer more resistance to cytotoxic agents in $3 \mathrm{D}$ multicellular conformation compared to that in monolayer culture. ${ }^{34,35}$ Therefore, we investigated the effect of APP on the growth of BT549 cells in 3D Matrigel. BT549 cells were cultured and treated with APP at the indicated doses for $24 \mathrm{~h}$ to measure the cellular viability and caspase activity using the ApoTox-Glo assay. APP exposure to BT549 cells decreased cell viability and concomitantly increased caspase $3 / 7$ activity in a dose-dependent manner compared to those in vehicle-treated cells in 3D culture (Figure 4A,B).

As phosphorylation of specific tyrosine residues in the EGFR is required for the activation of the $\mathrm{SH} 2$ domain containing downstream signaling proteins, we analyzed the effect of APP on pivotal downstream effectors by western blot analysis. It was observed that increasing doses of APP decreased the activation of p44/42 MAP kinase (phosphorylation at Y204) and STAT3 (phosphorylation at Y705), which indicates that APP decreases the activity of EGFR downstream effectors (Figure 4C). However, the treatment of cells with APP exhibited no effect on the expression of total ERK or STAT3 protein.

APP Modulates the Expression of Cell Cycle Regulators and Apoptotic Proteins in BT549 Cells. Next, we evaluated the effect of APP on the expression of pro-survival and cell cycle regulatory proteins in BT549 cells using western blotting. APP significantly decreased the expression of cell cycle regulators such as cyclin D1, cyclin B1, and c-Myc in a concentration-dependent manner. However, treatment with APP did not alter the expression of CDK4, a protein which facilitates the G1/S transition in association with cyclin $\mathrm{D} 1 .^{36}$ In addition, phosphorylation of CDK2 at T160 and the formation of the $\mathrm{CDK} 2 /$ cyclin A complex is required for G2/M cell cycle progression. Our results demonstrated decreased phosphorylation of CDK2 at T160, indicative of reduced activity of CDK2 (Figure 4C).

The activation of the EGFR has also been reported to modulate apoptosis. ${ }^{37}$ Therefore, we further analyzed whether APP modulated the expression of proapoptotic or antiapoptotic protein. We observed decreased expressions of BCL2 and BCL$\mathrm{xL}$ (Figure 4C). Additionally, we also observed the increased expression of the proapoptotic $\mathrm{BAD}$ protein, cytochrome $c$, and cleaved caspase 3 in a dose-dependent manner with maximum activity at $5 \mu \mathrm{M}$ (Figure $4 \mathrm{C}$ ), suggesting that APP relays apoptotic signals in TNBC cells at multiple levels to render its effect. 


\section{A. Cell viability}


\section{Western blot}

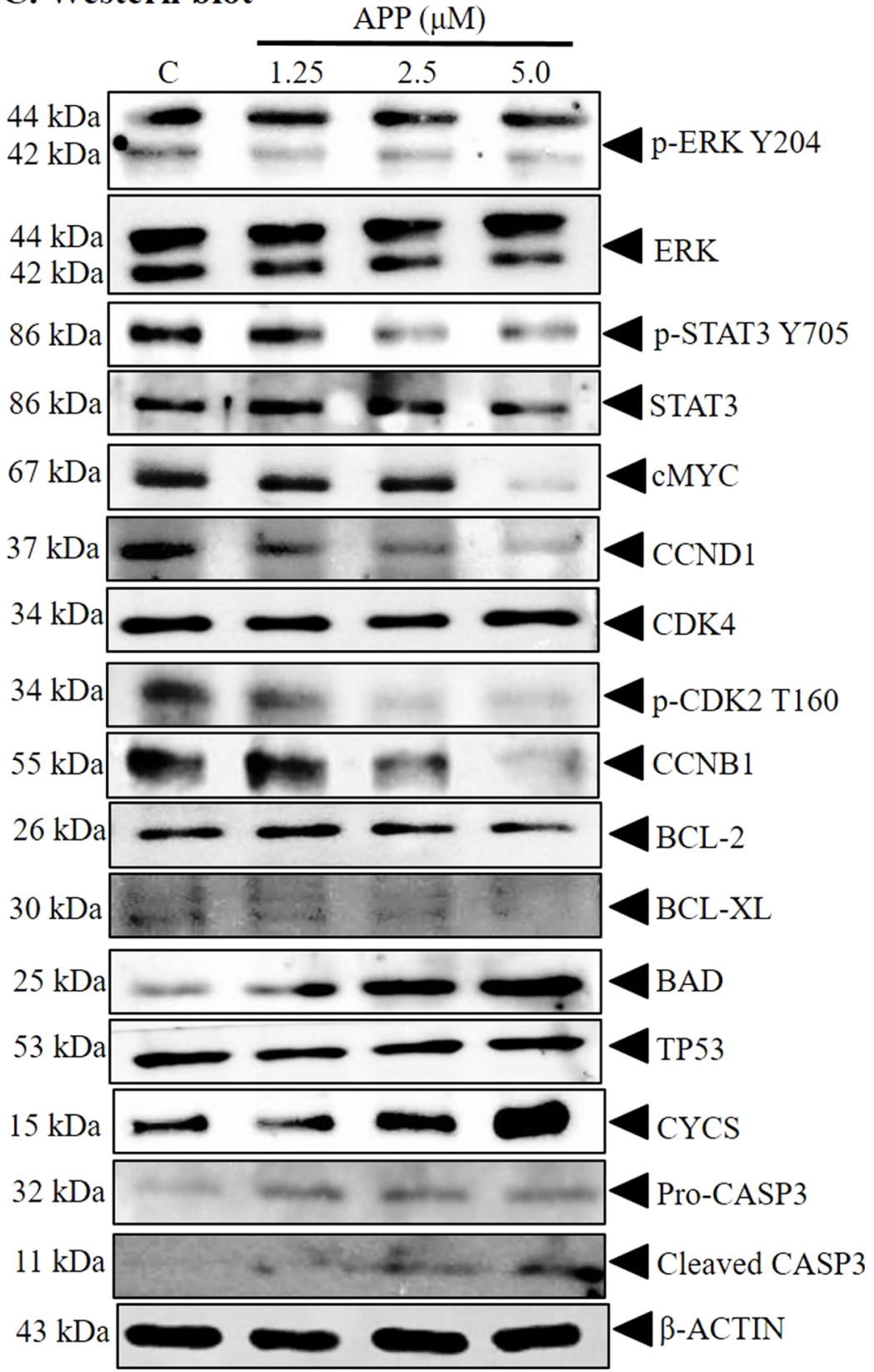

Figure 4. Exposure of APP to BT549 cells stimulates apoptosis in 3D matrigel culture and decreases expression of the downstream molecular effectors of EGFR signaling. (A) Cell viability and (B) caspase 3/7 activities were evaluated using the ApoTox-Glo Triplex assay kit (Promega) as described in Methods. Cell viability fluorescence is measured at $400_{\mathrm{Ex}} / 505_{\mathrm{Em}}$, and apoptosis (caspase 3/7 activities) is determined by luminescence measurement. The morphology of BT549-cells-generated colonies after exposure to APP and vehicle control is represented below. Images were captured under 100 $\times$ magnification using a bright field microscope (Nikon, Japan). (C) Western blot analysis was performed to evaluate the effect of APP on the downstream molecular effectors of EGFR signaling in BT549 cells. Soluble whole cell extracts were run on SDS-PAGE and immunoblotted as described in Methods. $\beta$-Actin was used as input control for cell lysate. The sizes of the detected protein bands in kilodaltons are shown on the left side. All assays were performed as described in Methods. Column points are mean of triplicate experiments; bars, \pm SD. $*_{p}<0.05$, $* * p<0.01$, and $* * * p<0.001$.

APP Decreases TNBC Cell Invasion and Migration. EGFR signaling promotes cancer cell migration and invasion by promoting an epithelial-mesenchymal transition (EMT)-like phenotype change accompanied by MMP-9-mediated degradation of E-cadherin. ${ }^{33,38-40}$ Therefore, we evaluated whether APP modulates the motility of TNBC cells. Figure 5A demonstrated that APP significantly suppressed the migration of BT549 cells at $5 \mu \mathrm{M}$. Furthermore, we investigated the effect of APP on cellular invasion using transwell invasion chambers. APP restricted cell invasion through the membrane by nearly $50 \%$ at $5 \mu \mathrm{M}$, demonstrative of the anti-invasive potential of APP (Figure 5B).

APP Modulates the Expression of EMT-Related Proteins. Increased expression of $\mathrm{N}$-cadherin has been implicated in metastasis and loss of occludin and E-cadherin is correlated with cell invasion and a negative prognosis in various human cancers. ${ }^{41-43}$ Therefore, we investigated whether APP modulated the expression of proteins characteristic of EMT such as $\mathrm{N}$-cadherin, occludin, and E-cadherin. The treatment of BT549 cells with APP decreased the expression of N-cadherin 


\section{A. Wound healing assay}
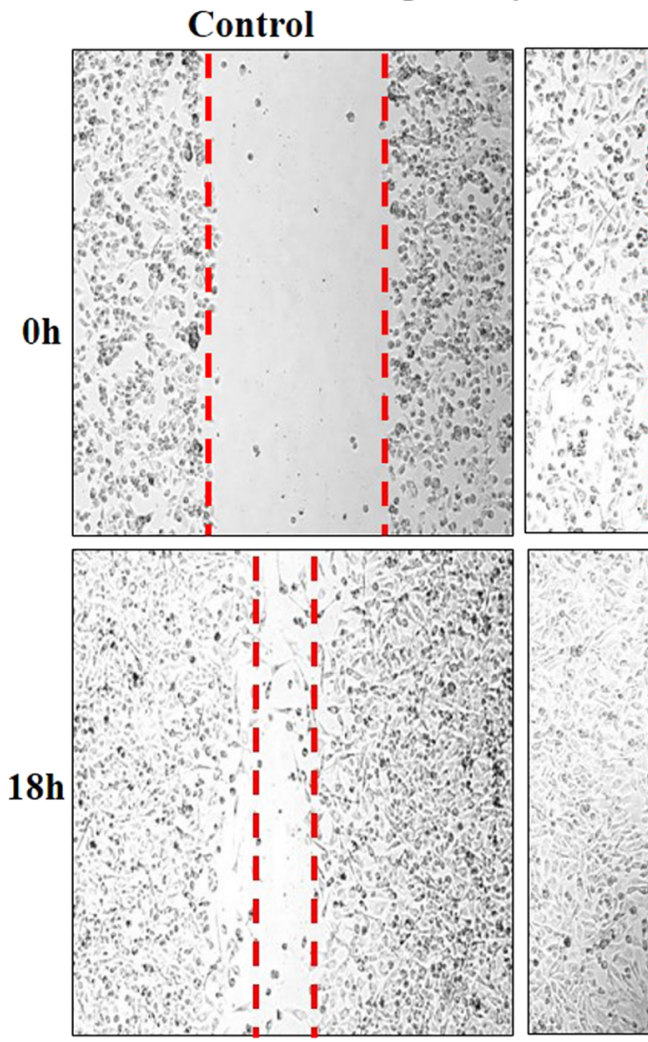

APP 5 $\mu \mathrm{M}$

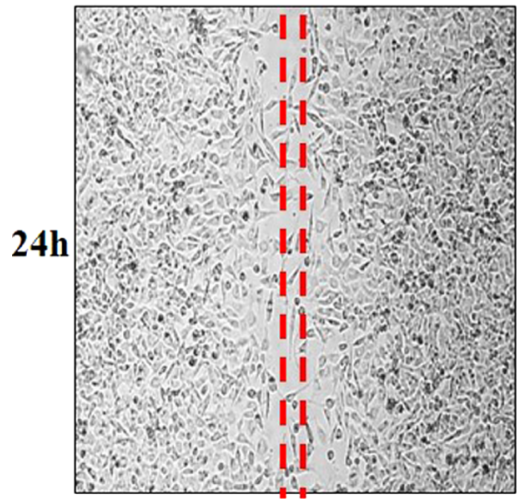

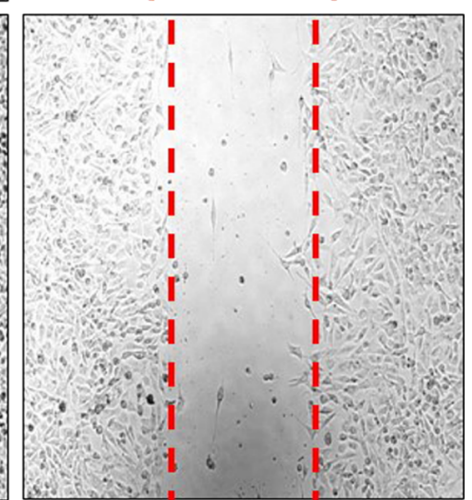

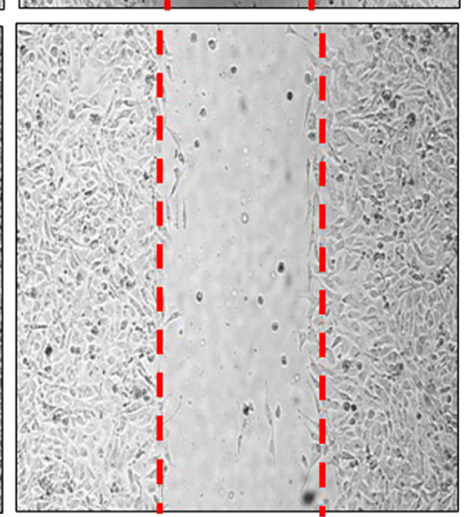

\section{B. Cell invasion}


\section{Western blot}

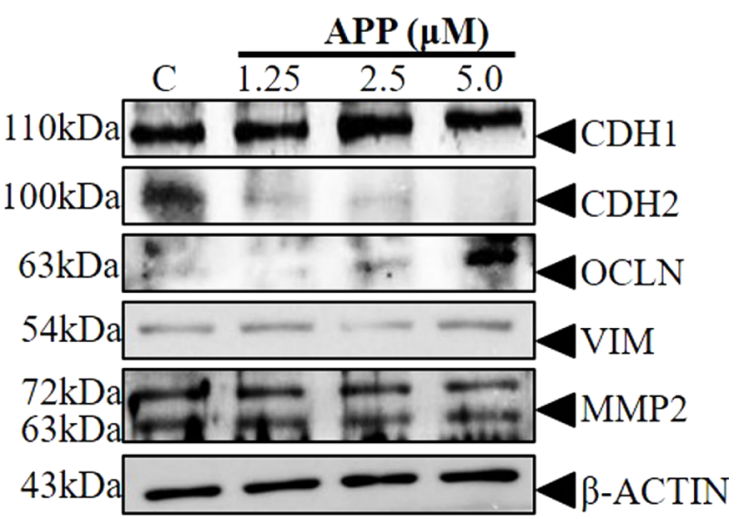

Figure 5. APP suppresses the migration and invasion and modulates the expression of EMT-related proteins in BT549 cells. (A) Migration assay: BT549 cells were plated on a $6 \mathrm{~cm}$ culture dish. After $24 \mathrm{~h}$ incubation, the medium was removed and a scratch was done using P200 pipette tip. The cells were then rinsed twice with phosphate-buffered saline (PBS) before APP treatment. The migration of cells was monitored at $0-24 \mathrm{~h}$ using bright field microscopy. (B) Transwell invasion assay: BT549 cells were suspended in a serum-free Dulbecco's modified eagle medium (DMEM) and seeded in the top chamber of a 5\% Matrigel in a 24-well Transwell insert (Greiner bio-one ThinCert 24-well culture insert; $8.0 \mu \mathrm{M}$ ). Thereafter, APP and DMSO in serum-free media were added followed by DMEM containing $10 \%$ fetal bovine serum (FBS). After $24 \mathrm{~h}$ incubation, Transwell inserts were fixed in $4 \%$ paraformaldehyde for $15 \mathrm{~min}$ at $4{ }^{\circ} \mathrm{C}$ and stained with Hoechst dye. Cell nuclei were counted and plotted in percentage. (C) Western blot analysis was performed to evaluate the effect of APP on the expression of EMT-related proteins (E-cadherin, N-cadherin, and occludin) in BT549 cells. Soluble whole cell extracts were run on SDS-PAGE and immunoblotted as described in Methods. $\beta$-Actin was used as input control for cell lysate. The sizes of the detected protein bands in kilodaltons are shown on the left side. All assays were performed as described in Methods. Column points are mean of triplicate experiments; bars, \pm SD. $* p<0.05, * * p<0.01$, and $* * * p<0.001$.

and increased the expressions of occludin and E-cadherin in a dose-dependent manner up to $5 \mu \mathrm{M}$ (Figure 5C).

siRNA-Mediated Depletion of EGFR Expression Prevented the Effect of APP in Breast Cancer Cell Lines. Next, we evaluated the functional specificity of APP toward EGFR by siRNA-mediated depletion of EGFR transcripts in BT549 and MDA-MB-231 cells. Transient transfection of EGFR-directed siRNA in both cell lines resulted in decreased levels of the phospho-EGFR (Y1045, Y1068, and Y1086) and total EGFR when compared with those of the respective scrambled siRNA control (Figure 6A). The treatment of the scrambled-siRNAtransfected cells with APP significantly suppressed the phosphorylation (Y1045, Y1068, Y1086) of the EGFR compared to that of DMSO-treated cells. In parallel, the treatment of cells with APP significantly increased apoptosis compared to DMSOtreated cells. However, APP did not affect the cell viability in either cell line with depleted expression of the EGFR (Figure $6 \mathrm{~B}, \mathrm{C})$. 
A. Western blot

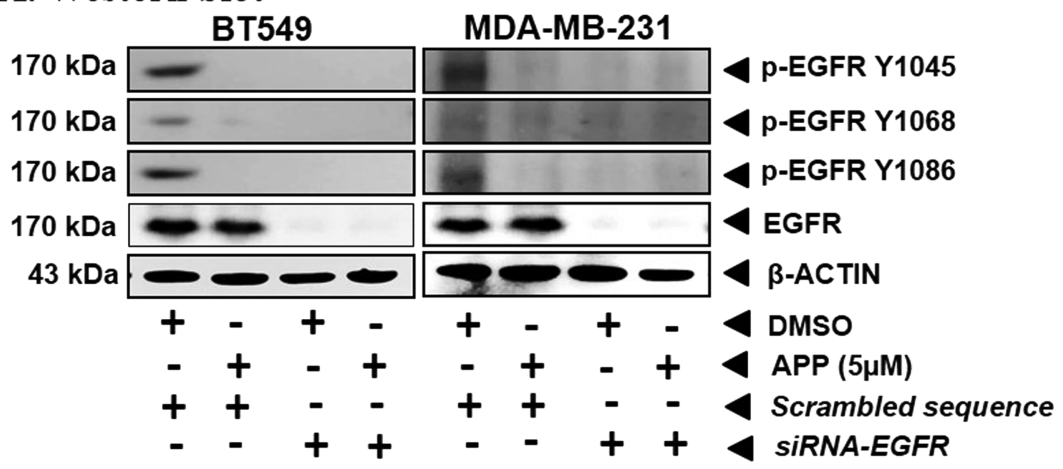

B. Cell viability
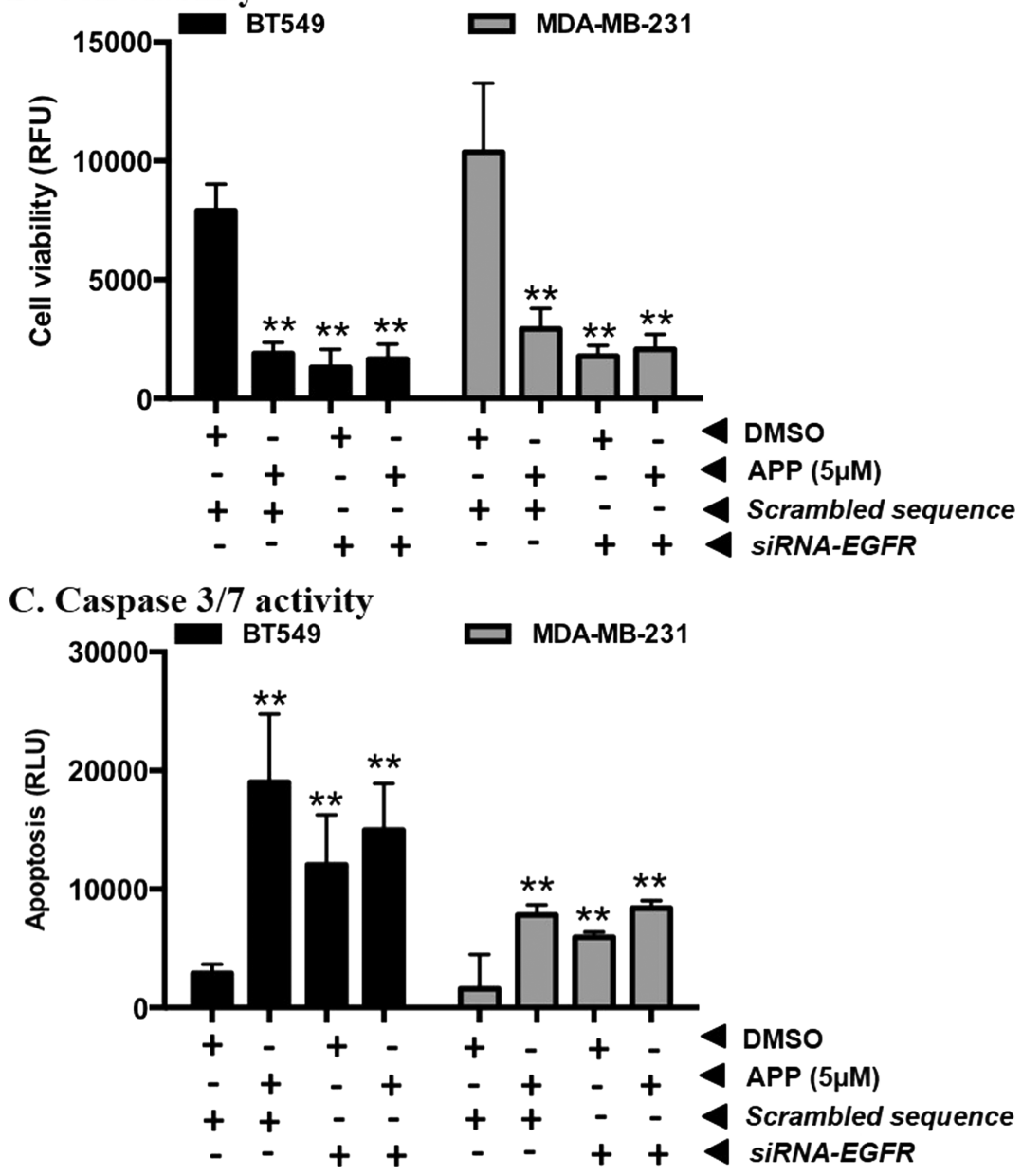

Figure 6. siRNA-mediated depletion of EGFR expression prevents the effect of APP in BT549 and MDA-MB-231 cells. (A) Western blot analysis was performed to analyze the levels of phospho-EGFR (Y1045, Y1068, Y1086) and total EGFR protein in BT549 and MDA-MB-231 cells after siRNAmediated depletion of EGFR transcripts and/or exposure to APP. Depletion of EGFR expression was achieved using transient transfection of si-RNA directed to EGFR transcripts. Soluble whole cell extracts were run on SDS-PAGE and immunoblotted as described in Methods. $\beta$-Actin was used as input control for cell lysate. The sizes of the detected protein bands in kilodaltons are shown on the left side. (B) Cell viability and (C) caspase 3/7 activities were evaluated in BT549 and MDA-MB-231 cells after siRNA-mediated depletion of EGFR transcripts and/or exposure to APP using the ApoTox-Glo Triplex assay kit as described in Methods. Cell viability fluorescence was measured at $400_{\mathrm{Ex}} / 505_{\mathrm{Em}}$ and cytotoxicity fluorescence was measured at $485_{\mathrm{Ex}} / 520_{\mathrm{Em}}$, whereas apoptosis (caspase $3 / 7$ activities) was determined by luminescence measurement. Statistical significance was assessed by an unpaired two-tailed Student's $t$-test $(p<0.05$ was considered as significant) using GraphPad Prism5. Columns are mean of triplicate experiments; bars, \pm SD. $* p<0.05, * * p<0.01$, and $* * * p<0.001$. Note: RFU, relative fluorescence unit; RLU, relative luminescence unit.

\section{DISCUSSION}

Therapeutic targeting in TNBC is a clinical challenge because of the lack of HER2, ER, and PR, for which effective therapeutics are available. However, TNBC exhibits increased expression of the EGFR in approximately half of the cases and is considered as one of the chief contributors to the negative prognosis of TNBC. ${ }^{5}$ Hence, there has been a significant focus to design EGFR inhibitors for use in EGFR-positive TNBC. ${ }^{7}$ Previous findings suggest that EGFR signaling regulates tumor cell migration in adamantinomatous craniopharyngiomas and that treatment with 
gefitinib reduces tumor cell motility. ${ }^{38}$ EGFR signaling has been demonstrated to promote EMT, which is considered as a critical process in regulating cell motility. ${ }^{44}$ During EMT, a variety of epithelial cells change their morphology from a polarized epithelial phenotype (loss of epithelial markers such as Ecadherins and cytokeratins) to a mesenchymal fibroblastoid phenotype (expression of vimentin and fibronectin) and favor cell migration and invasion, which demonstrates the multifaceted role of the EGFR in pathogenesis.?

The key role of the EGFR in negative prognosis in various malignancies resulted in the development of numerous antiEGFR agents, and several of them have been advanced to the clinic. ${ }^{12}$ Moreover, several synthetic small molecules and monoclonal antibodies targeting the EGFR family tyrosine kinases in breast cancer are in different phases of trials. ${ }^{45}$ Cetuximab is an immunoglobulin G1 chimeric mouse-human monoclonal antibody, which targets the extracellular domain of the EGFR and has been approved for combinational therapy with irinotecan in the treatment of EGFR-expressing metastatic colorectal cancer (CRC) refractory patients. ${ }^{46}$ Similarly, Panitumumab, a humanized immunoglobulin G2 monoclonal antibody, acts by blocking the interaction between the EGF and EGFR and has been approved for the treatment of EGFRexpressing metastatic CRC patients. ${ }^{47}$ Moreover, several heterocyclic small molecules have been approved for the treatment of various cancers including breast cancer. Recently, in 2015, gefitinib, a quinazolin-4-amine derivative and an inhibitor of the EGFR, was approved for first-line treatment of patients with metastatic nonsmall-cell lung cancer. ${ }^{47}$ Also, gefitinib is in phase-II of clinical trials against triple-negative, EGFR-positive metastatic breast cancer. ${ }^{48}$ In another phase-II study, a combination of erlotinib with carboplatin and docetaxel showed promising results in the treatment of TNBC patients with a pathological complete response of $40 \%{ }^{49,50}$ Notably, several studies have shown the insensitivity of EGFR-expressing tumors to anti-EGFR agents, indicating the EGFR-independent tumor survival and the demand of combinational therapy targeting alternative signaling pathways along with anti-EGFR agents. ${ }^{7,51}$ Therefore, in the present study, we report the synthesis of chemically novel, biologically active EGFR inhibitors for use in TNBCs. The experimental data of our studies present the growth inhibitory effects of the lead structure against a panel of TNBC cells. Utilizing the platform of the in silico target prediction tool, APP appears to have potential inhibitory effects against the EGFR. Consistent with the in silico computational analysis, APP inhibited the phosphorylation of the key tyrosine residues of EFGR and the activity of downstream effectors including ERK and STAT3. In addition, APP was found to induce apoptosis and suppress proliferation, migration, and invasion in TNBCs. Concordantly, APP modulated the expression of various proteins involved in cell cycle regulation, apoptosis, and EMT. Taken together, APP is presented as a potential novel agent against TNBC; however, additional mechanistic and preclinical studies are required to completely validate its potential.

\section{METHODS}

Chemistry. ${ }^{1} \mathrm{H}$ and ${ }^{13} \mathrm{C}$ NMR spectra were recorded using a Bruker WH-200 (400 MHz) spectrometer in $\mathrm{CDCl}_{3}$ or DMSO$d_{6}$ as a solvent. Chemical shifts are expressed as parts per million, and TMS was used as an internal standard. High-resolution mass spectra were recorded on a Bruker Daltonics instrument. The Elemental Vario Cube CHNS rapid Analyzer was used to carry out elemental analyses. The reaction progression was monitored using thin-layer chromatography (TLC)-precoated silica gel G plates, and the formation of products was visualized by irradiation with UV light $(254 \mathrm{~nm})$. All of the chemicals were purchased from Sigma-Aldrich.

General Procedure for the Synthesis of APT. To a suspension of chalcone ( 1 equiv) in $[\mathrm{BMIM}]\left[\mathrm{BF}_{4}\right]$ ( 5 vol), thiosemicarbazide ( 1.2 equiv) and piperidine ( $2-3$ drops) were added. The reaction mixture was heated to $80^{\circ} \mathrm{C}$ for $4 \mathrm{~h}$, and the completion of reaction was monitored by TLC. Upon completion, the mixture was cooled and charged with 2(adamantan-1-yl)acetylbromide ( 1 equiv) into the reaction flask. The reaction mixture was further heated for $2 \mathrm{~h}$ at $80{ }^{\circ} \mathrm{C}$ and allowed to cool down. Thereafter, the mixture was filtered under vacuum, crystallized using appropriate solvent, and dried. All of the newly prepared compounds displayed consistent spectral properties with the assigned structures. All of the compounds were characterized by their spectroscopic $\left({ }^{1} \mathrm{H}, \mathrm{IR}\right.$, mass, elemental, and ${ }^{13} \mathrm{C}$ NMR) analyses.

4-(Adamantan-1-yl)-2-(3,5-diphenyl-4,5-dihydro-1H-pyrazol-1-yl)thiazole (3a). White solid; mp: $158{ }^{\circ} \mathrm{C}$; ${ }^{1} \mathrm{H}$ NMR (400 $\left.\mathrm{MHz}, \mathrm{CDCl}_{3}\right): 7.90(\mathrm{~m}, 3 \mathrm{H}), 7.77-7.21(\mathrm{~m}, 7 \mathrm{H}), 6.09(\mathrm{~s}, 1 \mathrm{H})$, $5.86(\mathrm{t}, 1 \mathrm{H}), 3.91-3.82\left(\mathrm{dd}, J_{1}=J_{2}=16,1 \mathrm{H}\right), 3.40-3.32\left(\mathrm{dd}, J_{1}=\right.$ $\left.J_{2}=8,1 \mathrm{H}\right), 1.98(\mathrm{~s}, 4 \mathrm{H}), 1.76-1.70(\mathrm{~m}, 11 \mathrm{H}) ;{ }^{13} \mathrm{C} \mathrm{NMR}$ $\left(\mathrm{CDCl}_{3}\right): 164.43,152.49,146.16,136.72,129.74,128.69,128.44$, 127.02, 126.41, 100.16, 64.85, 42.99, 41.48, 36.86, 36.45, 28.53; HRMS Calcd 462.1974; found, $462.1976\left(\mathrm{M}+\mathrm{Na}^{+}\right)$; Anal. Calcd for $\mathrm{C}_{28} \mathrm{H}_{29} \mathrm{~N}_{3} \mathrm{~S}$ : C, 76.50; H, 6.65; N, 9.56; S, 7.29; found: C, 76.51; H, 6.67; N, 9.53; S, 7.29.

4-(Adamantan-1-yl)-2-(5-(4-bromophenyl)-3-phenyl-4,5dihydro-1H-pyrazol-1-yl)thiazole (3b). Yellow solid; mp: 185 ${ }^{\circ} \mathrm{C}$; ${ }^{1} \mathrm{H} \mathrm{NMR}\left(400 \mathrm{MHz}, \mathrm{CDCl}_{3}\right): 7.7-7.4(\mathrm{~m}, 4 \mathrm{H}), 7.3-7.2(\mathrm{~m}$, $5 \mathrm{H}), 6.0(\mathrm{~s}, 1 \mathrm{H}), 5.6(\mathrm{t}, 1 \mathrm{H}), 3.8(\mathrm{dd}, 1 \mathrm{H}), 3.2(\mathrm{dd}, 1 \mathrm{H}), 2-1.6$ $(\mathrm{m}, 15 \mathrm{H})$; LCMS Calcd 517.1; found, $518(\mathrm{M}+\mathrm{H})$; Anal. Calcd for $\mathrm{C}_{28} \mathrm{H}_{28} \mathrm{BrN}_{3} \mathrm{~S}$ : C, 64.86; H, 5.44; N, 8.10; found: C, 64.83; $\mathrm{H}$, 5.43; N, 8.13.

4-(Adamantan-1-yl)-2-(5-(4-nitrophenyl)-3-phenyl-4,5-dihydro-1H-pyrazol-1-yl)thiazole (3c). Yellow solid; mp: $178{ }^{\circ} \mathrm{C}$; ${ }^{1} \mathrm{H}$ NMR $\left(400 \mathrm{MHz}, \mathrm{CDCl}_{3}\right): 7.7(\mathrm{~m}, 4 \mathrm{H}), 7.4-7.1(\mathrm{~m}, 5 \mathrm{H}), 6.0$ (s, $1 \mathrm{H}), 5.5(\mathrm{t}, 1 \mathrm{H}), 4(\mathrm{dd}, 1 \mathrm{H}), 3.3(\mathrm{dd}, 1 \mathrm{H}), 2-1.5(\mathrm{~m}, 15 \mathrm{H})$; LCMS Calcd 484.6; found: $485.4(\mathrm{M}+\mathrm{H})$; Anal. Calcd for $\mathrm{C}_{28} \mathrm{H}_{28} \mathrm{~N}_{4} \mathrm{O}_{2} \mathrm{~S}$ : C, 69.40; H, 5.82; N, 11.56; found: C, 69.43; $\mathrm{H}$, $5.88 ; \mathrm{N}, 11.52$.

4-(Adamantan-1-yl)-2-(3-(4-bromophenyl)-5-(4-methoxyphenyl)-4,5-dihydro-1H-pyrazol-1-yl)thiazole (3d). Yellow solid; mp: $219{ }^{\circ} \mathrm{C}$; ${ }^{1} \mathrm{H}$ NMR (400 $\left.\mathrm{MHz}, \mathrm{CDCl}_{3}\right)$ : 7.6-7.29 $(\mathrm{m}, 6 \mathrm{H}), 6.84(\mathrm{~d}, J=12,2 \mathrm{H}), 6.0(\mathrm{~s}, 1 \mathrm{H}), 5.6(\mathrm{t}, 1 \mathrm{H}), 3.8-3.71$ $(\mathrm{m}, 4 \mathrm{H}), 3.3-3.2\left(\mathrm{dd}, J_{1}=J_{2}=8,1 \mathrm{H}\right), 2.1-1.6(\mathrm{~m}, 15 \mathrm{H}) ;{ }^{13} \mathrm{C}$ $\operatorname{NMR}\left(\mathrm{CDCl}_{3}\right): 164.16,159.07,133.50,131.84,130.68,128.39$, 127.72, 123.68, 113.75, 100.33, 98.27, 64.44, 55.31, 42.53, 41.61, 41.13, 40.96, 36.91, 36.50, 36.11, 35.61, 28.56, 27.93; LCMS Calcd 547.1; found, 548.2 (M + H); Anal. Calcd for $\mathrm{C}_{29} \mathrm{H}_{30} \mathrm{BrN}_{3} \mathrm{OS}$ : C, 63.50; H, 5.51; N, 7.66; found: C, 63.49; $\mathrm{H}, 5.54 ; \mathrm{N}, 7.67$.

APP (3e). White solid; mp: $177{ }^{\circ} \mathrm{C}$; ${ }^{1} \mathrm{H}$ NMR (400 MHz, $\left.\mathrm{CDCl}_{3}\right): 7.77-7.67(\mathrm{~m}, 3 \mathrm{H}), 7.46-7.39(\mathrm{~m}, 3 \mathrm{H}), 7.32-7.28(\mathrm{~m}$, $1 \mathrm{H}), 7.08-7.05\left(\mathrm{t}, J_{1}=J_{2}=12,1 \mathrm{H}\right), 6.12(\mathrm{~s}, 1 \mathrm{H}), 5.56-5.50\left(\mathrm{t}, J_{1}\right.$ $\left.=J_{2}=12,1 \mathrm{H}\right), 3.90-3.80\left(\mathrm{dd}, J_{1}=J_{2}=16,1 \mathrm{H}\right), 3.38-3.29\left(\mathrm{dd}, J_{1}\right.$ $\left.=J_{2}=12,1 \mathrm{H}\right), 2.08-1.67(\mathrm{~m}, 15 \mathrm{H})$; LCMS Calcd 508.5; found, 510.2 (M+H); Anal. Calcd for $\mathrm{C}_{28} \mathrm{H}_{27} \mathrm{Cl}_{2} \mathrm{~N}_{3} \mathrm{~S}$ : C, 66.13; $\mathrm{H}, 5.35$; N, 8.26; found: C, 66.19; H, 5.34; N, 8.25.

4-(Adamantan-1-yl)-2-(3-(4-bromophenyl)-5-(4(trifluoromethyl)phenyl)-4,5-dihydro-1H-pyrazol-1-yl)- 
thiazole (3f). Yellow solid; mp: $165{ }^{\circ} \mathrm{C}$; ${ }^{1} \mathrm{H}$ NMR (400 MHz, $\left.\mathrm{CDCl}_{3}\right): 7.64-7.54(\mathrm{~m}, 3 \mathrm{H}), 7.27-7.17(\mathrm{~m}, 2 \mathrm{H}), 7.01-6.73(\mathrm{~m}$, $3 \mathrm{H}), 6.12(\mathrm{~s}, 1 \mathrm{H}), 5.69(\mathrm{t}, 1 \mathrm{H}), 3.91-3.82\left(\mathrm{dd}, J_{1}=J_{2}=16,1 \mathrm{H}\right)$, 3.49-3.30 (dd, $\left.J_{1}=J_{2}=8,1 \mathrm{H}\right), 1.99-1.70(\mathrm{~m}, 15 \mathrm{H})$; LCMS Calcd 585.1; found, 586.4 $(\mathrm{M}+\mathrm{H})$; Anal. Calcd for $\mathrm{C}_{29} \mathrm{H}_{27} \mathrm{BrF}_{3} \mathrm{~N}_{3} \mathrm{~S}$ : C, 59.39; $\mathrm{H}, 4.64 ; \mathrm{N}, 7.16$; found: C, 59.33; $\mathrm{H}, 4.66 ; \mathrm{N}, 7.21$.

4-(Adamantan-1-yl)-2-(3-(4-bromophenyl)-5-phenyl-4,5dihydro-1H-pyrazol-1-yl)thiazole (3g). Yellow solid; mp: 188 ${ }^{\circ} \mathrm{C} ;{ }^{1} \mathrm{H}$ NMR (400 MHz, $\left.\mathrm{CDCl}_{3}\right): 7.62-7.51(\mathrm{~m}, 4 \mathrm{H}), 7.25-$ $7.19(\mathrm{~m}, 5 \mathrm{H}), 6.11(\mathrm{~s}, 1 \mathrm{H}), 5.58(\mathrm{t}, 1 \mathrm{H}), 3.86-3.76\left(\mathrm{dd}, \mathrm{J}_{1}=\mathrm{J}_{2}=\right.$ $16,1 \mathrm{H}), 3.35-3.27\left(\mathrm{dd}, J_{1}=J_{2}=12,1 \mathrm{H}\right), 1.98-1.65(\mathrm{~m}, 15 \mathrm{H})$; LCMS Calcd 517.1; found, $518(\mathrm{M}+\mathrm{H})$; Anal. Calcd for $\mathrm{C}_{28} \mathrm{H}_{28} \mathrm{BrN}_{3} \mathrm{~S}$ : C, 64.86; $\mathrm{H}, 5.44 ; \mathrm{N}, 8.10$; found: $\mathrm{C}, 64.81 ; \mathrm{H}$, 5.40; N, 8.15.

4-(Adamantan-1-yl)-2-(5-(3-nitrophenyl)-3-phenyl-4,5-dihydro-1H-pyrazol-1-yl)thiazole (3h). Yellow solid; mp: $197^{\circ} \mathrm{C}$; ${ }^{1} \mathrm{H}$ NMR (400 MHz, $\mathrm{CDCl}_{3}$ ): 7.79-7.72 (m, 2H), 7.45-7.35 (m, 4H), 6.87-6.80 (m, 3H), $6.12(\mathrm{~s}, 1 \mathrm{H}), 5.57(\mathrm{t}, 1 \mathrm{H}), 3.91-$ $3.77\left(\mathrm{dd}, J_{1}=J_{2}=12,1 \mathrm{H}\right), 3.40-3.32\left(\mathrm{dd}, J_{1}=J_{2}=8,1 \mathrm{H}\right), 2.14-$ $1.72(\mathrm{~m}, 15 \mathrm{H})$; LCMS Calcd 484.6; found, $485.4(\mathrm{M}+\mathrm{H})$; Anal. Calcd for $\mathrm{C}_{28} \mathrm{H}_{28} \mathrm{~N}_{4} \mathrm{O}_{2} \mathrm{~S}$ : C, 69.40; $\mathrm{H}, 5.82 ; \mathrm{N}, 11.56$; found: $\mathrm{C}$, 69.38; H, 5.81; N, 11.57.

4-(Adamantan-1-yl)-2-(3-(4-bromophenyl)-5-(3-methoxyphenyl)-4,5-dihydro-1H-pyrazol-1-yl)thiazole (3i). Yellow solid; mp: $165{ }^{\circ} \mathrm{C}$; ${ }^{1} \mathrm{H}$ NMR (400 MHz, $\left.\mathrm{CDCl}_{3}\right)$ : 7.6-7.4 (m, $4 \mathrm{H}), 7.2(\mathrm{t}, 1 \mathrm{H}), 6.9(\mathrm{~m}, 2 \mathrm{H}), 6.7(\mathrm{~d}, 1 \mathrm{H}), 6.0(\mathrm{~s}, 1 \mathrm{H}), 5.5(\mathrm{t}$, $1 \mathrm{H}), 3.8-3.7(\mathrm{~m}, 4 \mathrm{H}), 3.2(\mathrm{dd}, 1 \mathrm{H}), 2.0-1.5(\mathrm{~m}, 15 \mathrm{H}) ;{ }^{13} \mathrm{C}$ NMR (DMSO- $\left.d_{6}\right)$ : 164.12, 162.87, 159.56, 151.70, 143.59, 132.26, 130.89, 129.92, 128.68, 123.44, 119.35, 113.60, 113.41, 101.23, 64.99, 55.46, 42.66, 41.75, 36.84, 36.44, 28.34; LCMS Calcd 547.1; found, 548.2 (M + H); Anal. Calcd for $\mathrm{C}_{29} \mathrm{H}_{30} \mathrm{BrN}_{3} \mathrm{OS}: \mathrm{C}$, 63.50; $\mathrm{H}, 5.51 ; \mathrm{N}, 7.66$; found: C, 63.47; $\mathrm{H}, 5.48 ; \mathrm{N}, 7.66$.

4-(Adamantan-1-yl)-2-(5-(4-methoxyphenyl)-3-(3-nitrophenyl)-4,5-dihydro-1H-pyrazol-1-yl)thiazole (3j). Yellow solid; mp: $197{ }^{\circ} \mathrm{C}$; ${ }^{1} \mathrm{H}$ NMR (400 $\left.\mathrm{MHz}, \mathrm{CDCl}_{3}\right)$ : 7.62-7.51 $(\mathrm{m}, 4 \mathrm{H}), 7.25-7.19(\mathrm{~m}, 1 \mathrm{H}), 6.96-6.93(\mathrm{~m}, 2 \mathrm{H}), 6.81-6.77(\mathrm{~m}$, $1 \mathrm{H}), 6.11(\mathrm{~s}, 1 \mathrm{H}), 5.58(\mathrm{t}, 1 \mathrm{H}), 3.86-3.76\left(\mathrm{dd}, J_{1}=J_{2}=16,4 \mathrm{H}\right)$, $3.35-3.27\left(\mathrm{dd}, J_{1}=J_{2}=12,1 \mathrm{H}\right), 1.98-1.59(\mathrm{~m}, 15 \mathrm{H})$; LCMS Calcd 514.4; found, $515.4(\mathrm{M}+\mathrm{H})$; Anal. Calcd for $\mathrm{C}_{29} \mathrm{H}_{30} \mathrm{~N}_{4} \mathrm{O}_{3} \mathrm{~S}$ : C, 67.68; H, 5.88; N, 10.89; found: C, 67.69; $\mathrm{H}, 5.85 ; \mathrm{N}, 10.92$.

4-(Adamantan-1-yl)-2-(5-(3-bromo-4-fluorophenyl)-3phenyl-4,5-dihydro-1H-pyrazol-1-yl)thiazole (3k). Yellow solid; mp: $225{ }^{\circ} \mathrm{C}$; ${ }^{1} \mathrm{H}$ NMR (400 $\mathrm{MHz}, \mathrm{CDCl}_{3}$ ): 7.77-7.67 (m, 3H), 7.46-7.39 (M, 3H), 7.32-7.28 (m, 1H), 7.08-7.02 $(\mathrm{m}, 1 \mathrm{H}), 6.12(\mathrm{~s}, 1 \mathrm{H}), 5.56-5.50\left(\mathrm{t}, J_{1}=J_{2}=12,1 \mathrm{H}\right), 3.90-3.80$ $\left(\mathrm{dd}, J_{1}=J_{2}=16,1 \mathrm{H}\right), 3.38-3.29\left(\mathrm{dd}, J_{1}=J_{2}=12,1 \mathrm{H}\right), 2.08-1.67$ $(\mathrm{m}, 15 \mathrm{H}) ;{ }^{13} \mathrm{C}$ NMR (DMSO- $\left.d_{6}\right): 163.17,161.68,151.82$, 138.76, 133.22, 130.41, 129.24, 128.18, 127.59, 125.76, 116.12, 115.90, 106.75, 100.21, 62.86, 40.70, 35.76, 35.36, 27.29; LCMS Calcd 535.1; found, 536.2 (M+H); Anal. Calcd for $\mathrm{C}_{28} \mathrm{H}_{27} \mathrm{BrFN}_{3} \mathrm{~S}: \mathrm{C}, 62.68 ; \mathrm{H}, 5.07 ; \mathrm{N}, 7.83$; found: $\mathrm{C}, 62.72 ; \mathrm{H}$, 5.05; N, 7.88 .

4-(Adamantan-1-yl)-2-(5-(4-methoxyphenyl)-3-phenyl4,5-dihydro-1H-pyrazol-1-yl)thiazole (3l). Yellow solid; mp: $159{ }^{\circ} \mathrm{C} ;{ }^{1} \mathrm{H} \mathrm{NMR}\left(400 \mathrm{MHz}, \mathrm{CDCl}_{3}\right): 7.8(\mathrm{~d}, 2 \mathrm{H}), 7.4-7.3(\mathrm{~m}$, $5 \mathrm{H}), 6.7(\mathrm{~m}, 2 \mathrm{H}), 6.0(\mathrm{~s}, 1 \mathrm{H}), 5.5(\mathrm{t}, 1 \mathrm{H}), 3.8(\mathrm{dd}, 1 \mathrm{H}), 3.7(\mathrm{~s}$, $3 \mathrm{H}), 3.3(\mathrm{dd}, 1 \mathrm{H}), 2.0-1.5(\mathrm{~m}, 15 \mathrm{H}) ;{ }^{13} \mathrm{C} \mathrm{NMR}\left(\mathrm{CDCl}_{3}\right)$ : $162.22,161.16,159.10,152.03,143.83,133.10,132.32,128.70$, 128.39, 126.52, 113.83, 100.16, 64.38, 55.31, 41.37, 40.91, 36.77, 36.42, 36.10, 28.49, 27.91; LCMS Calcd 469.6; found, 470.4 (M
$+\mathrm{H}$ ); Anal. Calcd for $\mathrm{C}_{29} \mathrm{H}_{31} \mathrm{~N}_{3} \mathrm{OS}$ : C, 74.17; H, 6.65; N, 8.95; found: C, 74.21; H, 6.68; N, 8.90;

Pharmacology. Cell Culture and Reagents. Human MC cell lines MCF7, BT474, T47D, MDA-MB-231, BT549, MDA-MB468 , HCC70, and BT20 were obtained from the ATCC and were cultured as per ATCC propagation instructions. Estrogenreceptor-positive $(\mathrm{ER}+) \mathrm{MC}$ cells, including MCF7, T47D, and BT474, were cultured in Roswell Park Memorial Institute (RPMI 1640) culture medium supplemented with penicillin-streptomycin (1\%) and FBS (10\%). DMEM supplemented with FBS $(10 \%)$ and penicillin-streptomycin (1\%) was used to culture ER-negative (ER-) MC cells including MDA-MB-231, BT549, MDA-MB-468, HCC70, and BT20. Cells were propagated in a tissue culture flask and cultured at $37{ }^{\circ} \mathrm{C}$ with $\mathrm{CO}_{2}(5 \%)$ in humidified incubators. Culture mediums were replaced every alternate day. EGFR-sequence-directed ON-TARGETplus EGFR siRNA (L-003114-00-0005) was purchased from Dharmacon. Cells were transiently transfected with siRNA oligo $(20 \mathrm{mM})$ or universal negative control oligo (Invitrogen, Carlsbad, CA) using FuGENE HD (Promega) for $24 \mathrm{~h}$ and further assays were performed. ${ }^{52}$ Hoechst 33258 reagent was purchased from ThermoFisher Scientific, and Hoechst staining was performed as described previously. ${ }^{53}$

Oncogenicity Assays. The biological assay, an AlamarBlue viability assay, was performed as described previously. ${ }^{52}$ Whole cell viability, apoptosis, and cytotoxicity were evaluated using the ApoTox-Glo Triplex assay kit, Promega (Singapore), according to manufacture's instructions. ${ }^{34}$ In brief, $2 \times 10^{4}$ cells were seeded in black opaque 96-well plates (Corning, Singapore) and incubated overnight at $37{ }^{\circ} \mathrm{C}$. Thereafter, $5 \mu \mathrm{M}$ of APP and vehicle control (DMSO) were added to the respective wells. After $24 \mathrm{~h}$ of incubation at $37{ }^{\circ} \mathrm{C}$, the viability/cytotoxicity reagent containing both the GF-AFC and bis-AAF-R110 substrates was added to the cells as indicated by the manufacturer. After $45 \mathrm{~min}$ of incubation at $37^{\circ} \mathrm{C}$, fluorescence was recorded at $400 \mathrm{~nm}$ excitation/505 nm emission for viability and at $485 \mathrm{~nm}$ excitation/520 $\mathrm{nm}$ emission for cytotoxicity using a Tecan microplate reader (Tecan, Singapore). Furthermore, the Caspase-Glo 3/7 reagent was added to the cells, the cells were incubated for $25 \mathrm{~min}$ at room temperature, and luminescence was recorded using Tecan microplate reader. Numbers of apoptotic, cytotoxic, and viable cells were measured in triplicates.

Flow Cytometry Analysis. The flow cytometric analysis was performed to study the effect of APP on the cell cycle of BT549 cells as described previously. ${ }^{54-56}$ Initially, cells were treated with $\mathrm{APP}$ at the indicated concentrations of $1.25,2.5$, and $5 \mu \mathrm{M}$ for 24 h. After the incubation, the cells were harvested, washed, and fixed with $70 \%$ ethanol, followed by incubation with $0.1 \%$ RNase A in PBS at $37^{\circ} \mathrm{C}$ for $30 \mathrm{~min}$. Thereafter, the cells were subjected to washing, re-suspension, and staining in PBS containing PI (25 $\mu \mathrm{g} / \mathrm{mL}$ ) for $30 \mathrm{~min}$ at room temperature. The distribution of cells across the cell cycle was analyzed with a Beckman Coulter flow cytometer.

3D Matrigel Culture Assay. The 3D matrigel culture assay was performed as reported previously. ${ }^{21,34}$ In brief, BD BioCoat Matrigel was coated on 48-well plates and $2 \%$ matrigel containing $5 \times 10^{4}$ cells was cast above the $100 \%$ matrigel layer and allowed to solidify. Thereafter, the cells were allowed to grow before subjecting them to treatment with different concentrations of APP $(1.25,2.5$, and $5 \mu \mathrm{M})$ in wild-type media containing $2 \%$ FBS.

Hoechst Staining. Cells were seeded in 12-well plates at 200 000 cells/well and allowed to settle overnight before treatment. ${ }^{57}$ 
After $24 \mathrm{~h}$ of treatment, the cells were fixed with $4 \%$ paraformaldehyde at room temperature for $15 \mathrm{~min}$. Then, the cells were washed with PBS and incubated with Hoechst 33342 for $15 \mathrm{~min}$ in the dark at room temperature. Finally, the stain was removed with PBS and the nuclei of cells were imaged by fluorescence microscopy. The percentage of apoptotic cells was assessed by counting the number of cells that displayed condensed and/or fragmented nuclei in three randomly selected fields at $20 \times$ magnification.

SPR Analysis. Real-time analysis of the interactions of APP with the EGFR was carried out on a Biacore 2000 instrument. SPR binding studies for this inhibitor and protein were performed. Initially, using a standard amine-coupling protocol of BIACORE, EGFR proteins were immobilized on a CM5 sensor chip in sodium acetate $(10 \mathrm{mM}, \mathrm{pH} 5.0)$ and its immobilization pattern was noted. Furthermore, SPR studies were performed at $25{ }^{\circ} \mathrm{C}$ in HBS-EP running buffer containing $1 \%$ DMSO. Injections were made using the quick inject mode at $15 \mu \mathrm{L} / \mathrm{min}$ with a compound dissociation time of $2 \mathrm{~min}$. Ligand injections were referenced to a blank surface and by a buffer blank. APP was allowed to interact with EGFR for 2 min and dissociate for another $2 \mathrm{~min}$. Using BIA evaluation software, the ligand and protein binding and fitting to a simple 1:1 Langmuir binding kinetic model were performed. The kinetic parameters, such as dissociation equilibrium constants $\left(K_{\mathrm{d}}\right)$ and association and dissociation rate constants $\left(k_{\mathrm{a}}\right.$ and $\left.k_{\mathrm{d}}\right)$, were determined. The sensograms obtained were overlaid using BIA evaluation software.

Immunoblot Analyses. Immunoblot analysis was performed as previously described ${ }^{58-60}$ using mouse anti- $\beta$-Actin, mouse anti-p-ERK, rabbit anti-ERK, mouse anti-p-EGFR (Y1045), mouse anti-p-EGFR (Y1148), mouse anti-p-EGFR (Y1173), mouse anti-CCND1, mouse anti-CDK4, mouse anti-CCNB1, rabbit anti-c-MYC, mouse anti-BCL2, mouse anti-BCL-XL, mouse anti-BAD, rabbit anti-CYCS, mouse anti-p-ERK (44/42), and rabbit anti-ERK antibodies were procured from Santa Cruz Biotechnology, CA. Mouse anti-CDH1, mouse anti-CDH2, rabbit anti-OCLN, rabbit anti-pSTAT3, and mouse anti-STAT3 antibodies were obtained from Abcam, Cambridge, MA. Rabbit anti-p-EGFR (Y992) and rabbit anti-p-CDK2 antibodies were obtained from Cell Signaling. Cell extracts were resolved on SDS-PAGE and immunoblotted, with the appropriate and respective antibodies. $\beta$-Actin was used as input control for cell lysate. The sizes of the detected protein bands are shown in kilodaltons on the left side.

Migration and Invasion Assay. Cell migration and invasion assays were carried out using $\mathrm{BD}$ BioCoat Matrigel invasion chambers (BD Biosciences, Bedford, MA) as previously described. ${ }^{22,61-63}$

Statistical Analysis. The numerical data provided are expressed as mean \pm SD from representative experiments $(n=$ 3 ), and statistical significances were calculated using GraphPad Prism version 6.0. Unpaired $t$-test with Welch's correction was conducted, and the significance is expressed according to the following convention: ${ }^{*} p<0.05, * * p<0.01$, and $* * * p<0.001$.

\section{ASSOCIATED CONTENT}

\section{S Supporting Information}

The Supporting Information is available free of charge on the ACS Publications website at DOI: 10.1021/acsomega.6b00251.

Overview of EGFR signaling and mechanism of action of the lead molecule; copies of ${ }^{1} \mathrm{H}$ and mass spectra for products $3 \mathrm{a}-\mathbf{l} ;{ }^{13} \mathrm{C}$ NMR spectra for products $\mathbf{3 a}, \mathbf{3 d}, \mathbf{3 i}$, 3k, and 31; in silico prediction of human targets for the title compounds (Figures S1-S30; Tables S1 and S2) (PDF)

\section{AUTHOR INFORMATION}

\section{Corresponding Authors}

*E-mail: salundibasappa@gmail.com (B.)

*E-mail: csipel@nus.edu.sg (P.E.L.).

*E-mail: rangappaks@yahoo.com (K.S.R.).

ORCID

Andreas Bender: 0000-0002-6683-7546

\section{Author Contributions}

${ }^{\bowtie}$ A.S., V.P., and C.D.M. contributed equally to this work.

\section{Author Contributions}

A.S., V.P., C.D.M., Y.T.C., S.R., S.P., L.H.M., and J.E.F. carried out the chemical, biological, and in silico studies. V.P., C.D.M., J.M., K.C.B., B.C.P., A.B., B., P.E.L., and K.S.R. interpreted the results and assisted in manuscript preparation. A.B., S.Y., B., P.E.L., and K.S.R. provided the tools and reagents for research and prepared the manuscript. All authors read and approved the final manuscript.

\section{Notes}

The authors declare no competing financial interest.

\section{ACKNOWLEDGMENTS}

This research was supported by University Grants Commission (41-257-2012-SR), Vision Group Science and Technology, Department of Science and Technology (No. SR/FT/LS-142/ 2012) to B. The research was also supported by University Grants Commission (UGC), India, and Institution of Excellence, University of Mysore, to K.S.R. C.D.M. thanks the University of Mysore for the Department of Science and TechnologyPromotion of University Research and Scientific Excellence (DST-PURSE) Research Associate fellowship.

\section{REFERENCES}

(1) Bosch, A.; Eroles, P.; Zaragoza, R.; Vina, J. R.; Lluch, A. Triplenegative breast cancer: molecular features, pathogenesis, treatment and current lines of research. Cancer Treat. Rev. 2010, 36, 206.

(2) Yersal, O.; Barutca, S. Biological subtypes of breast cancer: Prognostic and therapeutic implications. World J. Clin. Oncol. 2014, 5, 412.

(3) Brouckaert, O.; Wildiers, H.; Floris, G.; Neven, P. Update on triplenegative breast cancer: prognosis and management strategies. Int. J. Women's Health 2012, 4, 511.

(4) Munagala, R.; Aqil, F.; Gupta, R. C. Promising molecular targeted therapies in breast cancer. Indian J. Pharmacol. 2011, 43, 236.

(5) Crown, J.; O’Shaughnessy, J.; Gullo, G. Emerging targeted therapies in triple-negative breast cancer. Ann. Oncol. 2012, 23, vi56.

(6) Peddi, P. F.; Ellis, M. J.; Ma, C. Molecular basis of triple negative breast cancer and implications for therapy. Int. J. Breast Cancer 2012, 2012, No. 217185.

(7) Masuda, H.; Zhang, D.; Bartholomeusz, C.; Doihara, H.; Hortobagyi, G. N.; Ueno, N. T. Role of epidermal growth factor receptor in breast cancer. Breast Cancer Res. Treat. 2012, 136, 331.

(8) Nyati, M. K.; Morgan, M. A.; Feng, F. Y.; Lawrence, T. S. Integration of EGFR inhibitors with radiochemotherapy. Nat. Rev. Cancer 2006, 6, 876.

(9) Yarden, Y.; Sliwkowski, M. X. Untangling the ErbB signalling network. Nat. Rev. Mol. Cell Biol. 2001, 2, 127.

(10) Scaltriti, M.; Baselga, J. The epidermal growth factor receptor pathway: a model for targeted therapy. Clin. Cancer Res. 2006, 12, 5268. 
(11) Liao, J.; Gallas, M.; Pegram, M.; Slingerland, J. Lapatinib: new opportunities for management of breast cancer. Breast Cancer 2010, 2, 79.

(12) Rocha-Lima, C. M.; Soares, H. P.; Raez, L. E.; Singal, R. EGFR targeting of solid tumors. Cancer Control 2007, 14, 295.

(13) Lombardo, L. J.; Lee, F. Y.; Chen, P.; Norris, D.; Barrish, J. C.; Behnia, K.; Castaneda, S.; Cornelius, L. A. M.; Das, J.; Doweyko, A. M.; et al. Discovery of N-(2-Chloro-6-methyl- phenyl)-2-(6-(4-(2-hydroxyethyl)- piperazin-1-yl)-2-methylpyrimidin-4- ylamino)thiazole-5-carboxamide (BMS-354825), a Dual Src/Abl Kinase Inhibitor with Potent Antitumor Activity in Preclinical Assays. J. Med. Chem. 2004, 47, 6658. (14) Lu, Y.; Li, C.-M.; Wang, Z.; Ross, C. R.; Chen, J.; Dalton, J. T.; Li, W.; Miller, D. D. Discovery of 4-Substituted Methoxybenzoyl-arylthiazole as Novel Anticancer Agents: Synthesis, Biological Evaluation, and Structure-Activity Relationships. J. Med. Chem. 2009, 52, 1701.

(15) Koca, İ.; Özgür, A.; Coşkun, K. A.; Tutar, Y. Synthesis and anticancer activity of acyl thioureas bearing pyrazole moiety. Bioorg. Med. Chem. 2013, 21, 3859.

(16) Riganas, S.; Papanastasiou, I.; Foscolos, G. B.; Tsotinis, A.; Serin, G.; Mirjolet, J.-F.; Dimas, K.; Kourafalos, V. N.; Eleutheriades, A.; Moutsos, V. I.; et al. New Adamantane Phenylalkylamines with $\sigma$ Receptor Binding Affinity and Anticancer Activity, Associated with Putative Antagonism of Neuropathic Pain. J. Med. Chem. 2012, 55, 10241.

(17) Nautiyal, J.; Majumder, P.; Patel, B. B.; Lee, F. Y.; Majumdar, A. P. Src inhibitor dasatinib inhibits growth of breast cancer cells by modulating EGFR signaling. Cancer Lett. 2009, 283, 143.

(18) Lv, P. C.; Li, H. Q.; Sun, J.; Zhou, Y.; Zhu, H. L. Synthesis and biological evaluation of pyrazole derivatives containing thiourea skeleton as anticancer agents. Bioorg. Med. Chem. 2010, 18, 4606.

(19) Lv, P. C.; Li, D. D.; Li, Q. S.; Lu, X.; Xiao, Z. P.; Zhu, H. L. Synthesis, molecular docking and evaluation of thiazolyl-pyrazoline derivatives as EGFR TK inhibitors and potential anticancer agents. Bioorg. Med. Chem. Lett. 2011, 21, 5374.

(20) Lamoureux, G.; Artavia, G. Use of the adamantane structure in medicinal chemistry. Curr. Med. Chem. 2010, 17, 2967.

(21) Pandey, V.; Perry, J. K.; Mohankumar, K. M.; Kong, X. J.; Liu, S. M.; Wu, Z. S.; Mitchell, M. D.; Zhu, T.; Lobie, P. E. Autocrine human growth hormone stimulates oncogenicity of endometrial carcinoma cells. Endocrinology 2008, 149, 3909.

(22) Pandey, V.; Qian, P. X.; Kang, J.; Perry, J. K.; Mitchell, M. D.; Yin, Z.; Wu, Z. S.; Liu, D. X.; Zhu, T.; Lobie, P. E. Artemin stimulates oncogenicity and invasiveness of human endometrial carcinoma cells. Endocrinology 2010, 151, 909.

(23) Kajstura, M.; Halicka, H. D.; Pryjma, J.; Darzynkiewicz, Z. Discontinuous fragmentation of nuclear DNA during apoptosis revealed by discrete "sub-G1" peaks on DNA content histograms. Cytometry, Part A 2007, 71, 125 .

(24) Ashwini, N.; Garg, M.; Mohan, C. D.; Fuchs, J. E.; Rangappa, S.; Anusha, S.; Swaroop, T. R.; Rakesh, K. S.; Kanojia, D.; Madan, V.; et al. Synthesis of 1,2-benzisoxazole tethered 1,2,3-triazoles that exhibit anticancer activity in acute myeloid leukemia cell lines by inhibiting histone deacetylases, and inducing p21 and tubulin acetylation. Bioorg. Med. Chem. 2015, 23, 6157.

(25) Koutsoukas, A.; Lowe, R.; Kalantarmotamedi, Y.; Mussa, H. Y.; Klaffke, W.; Mitchell, J. B.; Glen, R. C.; Bender, A. In silico target predictions: defining a benchmarking data set and comparison of performance of the multiclass Naive Bayes and Parzen-Rosenblatt window. J. Chem. Inf. Model. 2013, 53, 1957.

(26) Bento, A. P.; Gaulton, A.; Hersey, A.; Bellis, L. J.; Chambers, J.; Davies, M.; Kruger, F. A.; Light, Y.; Mak, L.; McGlinchey, S.; et al. The ChEMBL bioactivity database: an update. Nucleic Acids Res. 2014, 42, D1083.

(27) Wang, Y.; Suzek, T.; Zhang, J.; Wang, J.; He, S.; Cheng, T.; Shoemaker, B. A.; Gindulyte, A.; Bryant, S. H. PubChem BioAssay: 2014 update. Nucleic Acids Res. 2014, 42, D1075.

(28) Kawakita, Y.; Seto, M.; Ohashi, T.; Tamura, T.; Yusa, T.; Miki, H.; Iwata, H.; Kamiguchi, H.; Tanaka, T.; Sogabe, S.; et al. Design and synthesis of novel pyrimido [4, 5-b] azepine derivatives as HER2/EGFR dual inhibitors. Bioorg. Med. Chem. 2013, 21, 2250.

(29) Yuan, J. W.; Wang, S. F.; Luo, Z. L.; Qiu, H. Y.; Wang, P. F.; Zhang, X.; Yang, Y. A.; Yin, Y.; Zhang, F.; Zhu, H. L. Synthesis and biological evaluation of compounds which contain pyrazole, thiazole and naphthalene ring as antitumor agents. Bioorg. Med. Chem. Lett. 2014, 24, 2324.

(30) Keerthy, H. K.; Mohan, C. D.; Sivaraman Siveen, K.; Fuchs, J. E.; Rangappa, S.; Sundaram, M. S.; Li, F.; Girish, K. S.; Sethi, G.; Basappa.; et al. Novel synthetic biscoumarins target tumor necrosis factor-alpha in hepatocellular carcinoma in vitro and in vivo. J. Biol. Chem. 2014, 289, 31879.

(31) Scaltriti, M.; Baselga, J. The Epidermal Growth Factor Receptor Pathway: A Model for Targeted Therapy. Clin. Cancer Res. 2006, 12, 5268.

(32) Oda, K.; Matsuoka, Y.; Funahashi, A.; Kitano, H. A comprehensive pathway map of epidermal growth factor receptor signaling. Mol. Syst. Biol. 2005, 1, No. 2005.0010.

(33) Gan, Y.; Shi, C.; Inge, L.; Hibner, M.; Balducci, J.; Huang, Y. Differential roles of ERK and Akt pathways in regulation of EGFRmediated signaling and motility in prostate cancer cells. Oncogene 2010, $29,4947$.

(34) Sulaiman, N. B.; Mohan, C. D.; Basappa, S.; Pandey, V.; Rangappa, S.; Bharathkumar, H.; Kumar, A. P.; Lobie, P. E.; Rangappa, K. S. An azaspirane derivative suppresses growth and induces apoptosis of ER-positive and ER-negative breast cancer cells through the modulation of JAK2/STAT3 signaling pathway. Int. J. Oncol. 2016, $49,1221$.

(35) Mohan, C. D.; Srinivasa, V.; Rangappa, S.; Mervin, L.; Mohan, S.; Paricharak, S.; Baday, S.; Li, F.; Shanmugam, M. K.; Chinnathambi, A.; et al. Trisubstituted-Imidazoles Induce Apoptosis in Human Breast Cancer Cells by Targeting the Oncogenic PI3K/Akt/mTOR Signaling Pathway. PLoS One 2016, 11, No. e0153155.

(36) Foster, J. S.; Henley, D. C.; Bukovsky, A.; Seth, P.; Wimalasena, J. Multifaceted regulation of cell cycle progression by estrogen: regulation of Cdk inhibitors and Cdc25A independent of cyclin D1-Cdk4 function. Mol. Cell. Biol. 2001, 21, 794.

(37) She, Q.-B.; Solit, D. B.; Ye, Q.; O’Reilly, K. E.; Lobo, J.; Rosen, N. The BAD protein integrates survival signaling by EGFR/MAPK and PI3K/Akt kinase pathways in PTEN-deficient tumor cells. Cancer Cell 2005, 8, 287.

(38) Hölsken, A.; Gebhardt, M.; Buchfelder, M.; Fahlbusch, R.; Blumcke, I.; Buslei, R. EGFR signaling regulates tumor cell migration in craniopharyngiomas. Clin. Cancer Res. 2011, 17, 4367.

(39) Alper, O.; Bergmann-Leitner, E. S.; Bennett, T. A.; Hacker, N. F.; Stromberg, K.; Stetler-Stevenson, W. G. Epidermal growth factor receptor signaling and the invasive phenotype of ovarian carcinoma cells. J. Natl. Cancer Inst. 2001, 93, 1375.

(40) Zuo, J. H.; Zhu, W.; Li, M. Y.; Li, X. H.; Yi, H.; Zeng, G. Q.; Wan, X. X.; He, Q. Y.; Li, J. H.; Qu, J. Q.; et al. Activation of EGFR promotes squamous carcinoma SCC10A cell migration and invasion via inducing EMT-like phenotype change and MMP-9-mediated degradation of Ecadherin. J. Cell. Biochem. 2011, 112, 2508.

(41) Singhai, R.; Patil, V. W.; Jaiswal, S. R.; Patil, S. D.; Tayade, M. B.; Patil, A. V. E-Cadherin as a diagnostic biomarker in breast cancer. North Am. J. Med. Sci. 2011, 3, 227.

(42) Martin, T. A.; Mansel, R. E.; Jiang, W. G. Loss of occludin leads to the progression of human breast cancer. Int. J. Mol. Med. 2010, 26, 723.

(43) Zhuo, H.; Jiang, K.; Dong, L.; Zhu, Y.; Lü, L.; Lü, Y.; Zhang, Y.; Zhang, H.; Ye, Y.; Wang, S. Overexpression of N-cadherin is correlated with metastasis and worse survival in colorectal cancer patients. Chin. Sci. Bull. 2013, 58, 3529.

(44) Radisky, D. C. Epithelial-mesenchymal transition. J. Cell Sci. 2005, $118,4325$.

(45) Seshacharyulu, P.; Ponnusamy, M. P.; Haridas, D.; Jain, M.; Ganti, A. K.; Batra, S. K. Targeting the EGFR signaling pathway in cancer therapy. Expert Opin. Ther. Targets 2012, 16, 15. 
(46) Wheeler, D. L.; Dunn, E. F.; Harari, P. M. Understanding resistance to EGFR inhibitors-impact on future treatment strategies. Nat. Rev. Clin. Oncol. 2010, 7, 493.

(47) Giusti, R. M.; Shastri, K. A.; Cohen, M. H.; Keegan, P.; Pazdur, R. FDA Drug Approval Summary: Panitumumab (Vectibix). Oncologist 2007, 12, 577.

(48) The Safety and Effects of Gefitinib in Triple-negative, EGFR Positive Metastatic Breast Cancer. https://clinicaltrials.gov/ct2/show/ study/NCT01732276.

(49) Tomao, F.; Papa, A.; Zaccarelli, E.; Rossi, L.; Caruso, D.; Minozzi, M.; Vici, P.; Frati, L.; Tomao, S. Triple-negative breast cancer: new perspectives for targeted therapies. OncoTargets Ther. 2015, 8, 177.

(50) Sharma, P.; Khan, Q. J.; Kimler, B. F.; Klemp, J. R.; Connor, C. J.; McGinness, M. K.; Mammen, J. M. W.; Tawfik, O. W.; Fan, F.; Fabian, C. J. Abstract P1-11-07: Results of a Phase II Study of Neoadjuvant Platinum/Taxane Based Chemotherapy and Erlotinib for Triple Negative Breast Cancer. Cancer Res. 2014, 70, No. P1-11.

(51) Buck, E.; Eyzaguirre, A.; Barr, S.; Thompson, S.; Sennello, R.; Young, D.; Iwata, K. K.; Gibson, N. W.; Cagnoni, P.; Haley, J. D. Loss of homotypic cell adhesion by epithelial-mesenchymal transition or mutation limits sensitivity to epidermal growth factor receptor inhibition. Mol. Cancer Ther. 2007, 6, 532.

(52) Pandey, V.; Wu, Z. S.; Zhang, M.; Li, R.; Zhang, J.; Zhu, T.; Lobie, P. E. Trefoil factor 3 promotes metastatic seeding and predicts poor survival outcome of patients with mammary carcinoma. Breast Cancer Res. 2014, 16, 429.

(53) Kang, J.; Perry, J. K.; Pandey, V.; Fielder, G. C.; Mei, B.; Qian, P. X.; Wu, Z. S.; Zhu, T.; Liu, D. X.; Lobie, P. E. Artemin is oncogenic for human mammary carcinoma cells. Oncogene 2009, 28, 2034.

(54) Pandey, V.; Jung, Y.; Kang, J.; Steiner, M.; Qian, P. X.; Banerjee, A.; Mitchell, M. D.; Wu, Z. S.; Zhu, T.; Liu, D. X.; et al. Artemin Reduces Sensitivity to Doxorubicin and Paclitaxel in Endometrial Carcinoma Cells through Specific Regulation of CD24. Transl. Oncol. 2010, 3, 218.

(55) Roopashree, R.; Mohan, C. D.; Swaroop, T. R.; Jagadish, S.; Raghava, B.; Balaji, K. S.; Jayarama, S.; Basappa; Rangappa, K. S. Novel synthetic bisbenzimidazole that targets angiogenesis in Ehrlich ascites carcinoma bearing mice. Bioorg. Med. Chem. Lett. 2015, 25, 2589.

(56) Anusha, S.; Mohan, C. D.; Ananda, H.; Baburajeev, C. P.; Rangappa, S.; Mathai, J.; Fuchs, J. E.; Li, F.; Shanmugam, M. K.; Bender, A.; et al. Adamantyl-tethered-biphenylic compounds induce apoptosis in cancer cells by targeting $\mathrm{Bcl}$ homologs. Bioorg. Med. Chem. Lett. 2016, $26,1056$.

(57) Mohan, C. D.; Bharathkumar, H.; Bulusu, K. C.; Pandey, V.; Rangappa, S.; Fuchs, J. E.; Shanmugam, M. K.; Dai, X.; Li, F.; Deivasigamani, A.; et al. Development of a novel azaspirane that targets the Janus kinase-signal transducer and activator of transcription (STAT) pathway in hepatocellular carcinoma in vitro and in vivo. J. Biol. Chem. 2014, 289, 34296.

(58) Kong, X.; Wu, W.; Yuan, Y.; Pandey, V.; Wu, Z.; Lu, X.; Zhang, W.; Chen, Y.; Wu, M.; Zhang, M.; et al. Human growth hormone and human prolactin function as autocrine/paracrine promoters of progression of hepatocellular carcinoma. Oncotarget 2016, 7, 29465.

(59) Baburajeev, C. P.; Dhananjaya Mohan, C.; Ananda, H.; Rangappa, S.; Fuchs, J. E.; Jagadish, S.; Sivaraman Siveen, K.; Chinnathambi, A.; Ali Alharbi, S.; Zayed, M. E.; et al. Development of Novel TriazoloThiadiazoles from Heterogeneous "Green" Catalysis as Protein Tyrosine Phosphatase 1B Inhibitors. Sci. Rep. 2015, 5, 14195.

(60) Keerthy, H. K.; Garg, M.; Mohan, C. D.; Madan, V.; Kanojia, D.; Shobith, R.; Nanjundaswamy, S.; Mason, D. J.; Bender, A.; Basappa.; et al. Synthesis and characterization of novel 2-amino-chromene-nitriles that target Bcl-2 in acute myeloid leukemia cell lines. PLoS One 2014, 9, No. e107118.

(61) Lau, W. H.; Pandey, V.; Kong, X.; Wang, X. N.; Wu, Z.; Zhu, T.; Lobie, P. E. Trefoil Factor-3 (TFF3) Stimulates De Novo Angiogenesis in Mammary Carcinoma both Directly and Indirectly via IL-8/CXCR2. PLoS One 2015, 10, No. e0141947.

(62) Bharathkumar, H.; Mohan, C. D.; Rangappa, S.; Kang, T.; Keerthy, H. K.; Fuchs, J. E.; Kwon, N. H.; Bender, A.; Kim, S.; Basappa.; et al. Screening of quinoline, 1,3-benzoxazine, and 1,3-oxazine-based small molecules against isolated methionyl-tRNA synthetase and A549 and HCT116 cancer cells including an in silico binding mode analysis. Org. Biomol. Chem. 2015, 13, 9381.

(63) Bharathkumar, H.; Paricharak, S.; Dinesh, K.; Siveen, K. S.; Fuchs, J. E.; Rangappa, S.; Mohan, C.; Mohandas, N.; Kumar, A. P.; Sethi, G. Synthesis, biological evaluation and in silico and in vitro mode-of-action analysis of novel dihydropyrimidones targeting PPAR- $\gamma$. RSC Adv. 2014, 4,45143 . 